\title{
A Review of Safety Issues that Pertain to the Use of WESF Cesium Chloride Capsules in an Irradiator
}

\author{
G. L. Tingey \\ E. J. Wheelwright \\ J. M. Lytle
}

July 1984

Prepared for the U.S. Department of Energy under Contract DE-AC06-76RLO 1830

Pacific Northwest Laboratory

Operated for the U.S. Department of Energy by Battelle Memorial Institute 


\title{
DISCLAIMER
}

This report was prepared as an account of work sponsored by an agency of the United States Government. Neither the United States Government nor any agency thereof, nor any of their employees, makes any warranty, express or implied, or assumes any legal liability or responsibility for the accuracy, completeness, or usefulness of any information, apparatus, product, or process disclosed, or represents that its use would not infringe privately owned rights. Reference herein to any specific commercial product, process, or service by trade name, trademark, manufacturer, or otherwise, does not necessarily constitute or imply its endorsement, recommendation, or favoring by the United States Government or any agency thereof. The views and opinions of authors expressed herein do not necessarily state or reflect those of the United States Government or any agency thereof.

\author{
PACIFIC NORTHWEST LABORATORY \\ operated by \\ BATTELLE \\ for the \\ UNITED STATES DEPARTMENT OF ENERGY \\ under Contract DE-AC06-76RLO 1830
}

\begin{tabular}{|c|c|}
\hline \multicolumn{2}{|c|}{$\begin{array}{l}\text { Printed in the United States of America } \\
\text { Available from } \\
\text { National Technical Information Service } \\
\text { United States Department of Commerce } \\
5285 \text { Port Royal Road } \\
\text { Springfield, Virginia } 22161\end{array}$} \\
\hline \multicolumn{2}{|c|}{$\begin{array}{l}\text { NTIS Price Codes } \\
\text { Microfiche } \mathrm{A} 01\end{array}$} \\
\hline \multicolumn{2}{|c|}{ Printed Copy } \\
\hline Pages & $\begin{array}{l}\text { Price } \\
\text { Codes }\end{array}$ \\
\hline $001-025$ & $\mathrm{~A} 02$ \\
\hline 026-050 & $\mathrm{A03}$ \\
\hline $051-075$ & $\mathrm{~A} 04$ \\
\hline $076-100$ & $\mathrm{~A} 05$ \\
\hline $101-125$ & $\mathrm{~A} 06$ \\
\hline $126-150$ & A07 \\
\hline $151-175$ & $\mathrm{~A} 0 \mathrm{~B}$ \\
\hline $176-200$ & $\mathrm{~A} 09$ \\
\hline $201-225$ & A010 \\
\hline $226-250$ & A011 \\
\hline $251-275$ & A012 \\
\hline $276-300$ & A013 \\
\hline
\end{tabular}


PNL-5170

\section{A REVIEW OF SAFETY ISSUES THAT PERTAIN TO THE USE OF WESF CESIUM CHLORIDE CAPSULES IN AN IRRADIATOR}
G. L. Tingey
E. J. Wheelwright
J. M. Lyt le

July 1984

Prepared for the U.S. Department of Energy under Contract OE-AC06-76RLO 1830

Pacific Northwest Laboratory Richland, Washington 99352 
Since the recovery of the fission product cesium- 137 began in 1967, about 1500 capsules, each containing an average of about 50,000 curies of cesium chloride, have been produced. These capsules were designed to safely store this gama-emitting fission product but are now considered to be a valuable source for irradiators.

Over the years, many tests have been conducted to enable selection of a proper containment material and to ensure the safety of the capsules in the projected environment. The resuits indicate that the capsules can be safely used in an irradiator and for ultimate disposal as well as for storage in the Waste Encapsulation and Storage Facility (WESF) pool. Corrosion studies have shown that $316 \mathrm{l}$ stainless steel is highly resistant to attack by pure cesium chloride at temperatures up to $600^{\circ} \mathrm{C}$. However, the impurities present in WESF cesium chloride react much more rapidly with the capsules, causing significant corrosion rates at temperatures of $450^{\circ} \mathrm{C}$. At irradiator temperatures (about $200^{\circ} \mathrm{C}$ at the sait/metal interface), the extent of corrosion was insignificant after 27 months as determined by analysis of a capsule from the Sandia Irradiator for Dried Sewage Solids (SIDSS). Furthermore, examination of the capsules is continuing to produce long-term corrosion data to reaffirm that the capsuies are capable of withstanding temperatures up to $800^{\circ} \mathrm{C}$ for short periods of time, to continue to monitor the long-term capsule mechanical properties, and to further assess the effects from thermal cycling during irradiation operation.

The capsules were designed to have a large margin of safety in their mechanical properties. Impact, percussion, and thermal tests have been conducted that demonstrate their ability to meet anticipated licensing requirements.

Although this document is not intended to develop or evaluate accident scenarios, an examination of the effects of heating a capsule to $800^{\circ} \mathrm{C}$ for up to 90 min was completed. At $800^{\circ} \mathrm{C}$, the salt volume would be expected to exceed the initial capsule volume in a few (up to 1/3) of the WESF capsules. Under these conditions, the inner capsule would expand to accommodate the 
:

salt volume and the gas pressure. The strength and ductility of the capsuie are more than adequate to permit this expansion with a safety margin of at least a factor of three.

Capsules have now been stored in the WESF pool for 10 years, and 15 capsules have been used in the SIDSS facility for nearly 5 years without any capsule failure. This experience, along with available laboratory and production data, gives reasonable assurance that the capsules can be safely used in properly designed commercial irradiators. This is especially the case when one considers current and future evaluation programs designed to assess the long-term effects of corrosion and mechanical properties degradation. 


\section{CONTENTS}

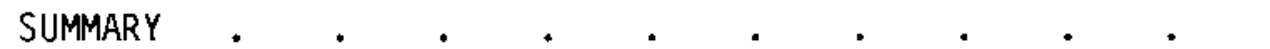

1.0 INTROOUCTION

1.1 OOCUMENT SCOPE .

1.2 WASTE MANAGEMENT GOAL

1.3 PREPARATION OF WESF CESIUM CHLORIDE CAPSULES

1.4 UTILIZATION OF WESF CAPSULES

2.0 CAPSULE PERFORMANCE REQUIREMENTS

3.0 POTENTIAL MECHANISMS FOR RELEASE OF CESIUM-137

3.1 CAPSULE CORROSION

3.1.1 Internal Capsule Corrosion . . . . . . . 13

3.1 .2 External Capsule Corrosion . . . . . . . . 26

3.1.3 Corrosion During Capsule Preparation . . . . . 26

3.2 THERMAL EXPANSION . . . . . . . . . . . . . . 27

3.2.1 Effects of Cesium Chloride Phase Transformations and Thermal Expansion . . . . . . . . 27

3.2.2 Effects of Decay Products and Impurities . . . 29

3.2.3 Volume of WESF Inner Capsules and the Annular Volume Between Inner and Outer Capsules.

3.2.4 Accommodation of Cesium Chloride in WESF Capsules

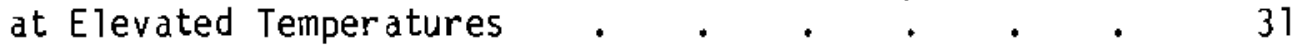

3.2.5 Summary of Thermal Expansion Analys is . . . . 37

3.3 CAPSULE MECHANICAL PROPERTIES . . . . . . . . . . 38

3.3.1 General Mechanical Properties of Capsules . . . 38

3.3.2 Impact, Percussion, and Fire Tests . . . . 40

3.3.3 Mechanical Properties of Aged Capsules . . . 42

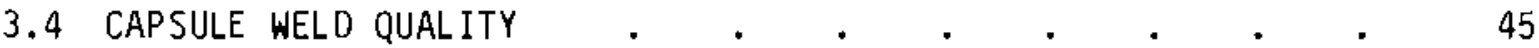

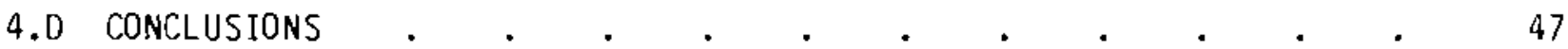

5.0 REFERENCES . . . . . . . . . . . . . . . . 51 


\section{FIGURES}

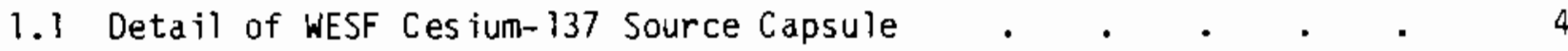

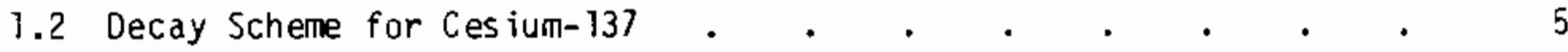

3.1 Volume Changes with Temperature for a New and a 30-Year-01d WESF Capsule Showing That the Inner Capsule Yields at Temperatures Above About $700^{\circ} \mathrm{C}$ But That the Outer Capsule Does Not Yieid Even at Temperatures Greater Than $1000^{\circ} \mathrm{C} \quad . \quad$. 33

3.2 Distribution of Loading Factors in WESF Cesium Chloride Capsules . 35

3.3 Volume Changes with Temperature for a New Maximum-Loaded WESF Capsule Showing Minimum Capsule Volume Coupled with Maximum Content Mass

\section{$\underline{\text { TABLES }}$}

2.1 Classification of Sealed Source Performance Tests . $\quad$ • $\quad$ • $\quad$. 8

2.2 Sealed Source Performance Requirements for Typical Usage . . . $\quad 9$

2.3 Activity Level Limits . . . . . . . . . . . . . . . 10

3.1 Estimates of Impurity Levels in WESF Cesium Chloride . . . . 15

3.2 Calculated Impurity Content in Eight WESF Cesium Capsules $\quad$ • $\quad$ • 17

3.3 Minimum Melting Points Dbserved in Certain Metal Chloride Systems ly

3.4 Estimated Meta? Attack in Thermally Aged WESF Cesium Chloride

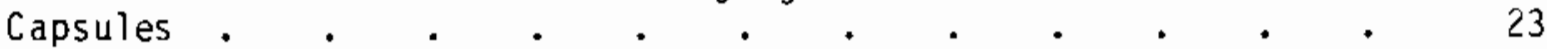

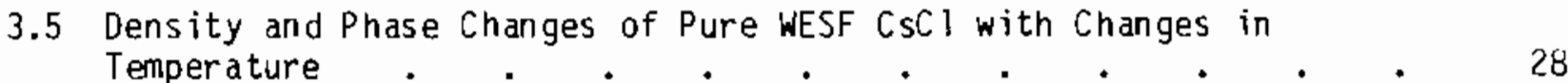

3.6 Effect of Iron Contaminants on the Volume of Aged ${ }^{137} \mathrm{CsC} 1$

3.7 Volumes of WESF Inner Capsules and the Annular Space Between
Inner and Outer Capsules at $25^{\circ} \mathrm{C}$ and $800^{\circ} \mathrm{C}$. . . . 32

3.8 Minimum Strength and Ductility Standards of the $316 \mathrm{~L}$ SS
Tubing Used in WESF CSCl Capsules

3.9 Dimensional Tolerances of WESF Tubing . . . . . . . . . . 39

3.10 Outer Diameter of A) Isolated Inner Capsule and B) Inner Capsule That Was Tested Inside the Outer Capsule After the Capsules Had Been Held in a $871^{\circ} \mathrm{C}$ Furnace for 90 min and Cooled Gradually . . . . 42

3.11 Comparison of Test Conditions Required by ANSI N542 Class 6 with Test Conditions Used for WESF Cesium Chloride Capsules. . 43

3.12 Sumary of Mechanical Properties at $25^{\circ} \mathrm{C}$ of "New" and "Aged"
$316 \mathrm{~L} S \mathrm{~S}$ from CSCl Capsules . $. . \quad . \quad . \quad . \quad . \quad . \quad 44$ 
. 


\subsection{INTRODUCTION}

\subsection{DOCUMENT SCDPE}

The use of cesium-137 chloride capsules produced at the Waste Encapsulation and Storage Facility (WESF) as a substitute for cobalt-60 in some irradiation facilities has been demonstrated at the Sandia National Laboratories and is proposed for commercial use (U.S. Department of Energy 1983). An appropriate overriding concern in the comercial use of WESF cesium chloride capsules is that capsule integrity will not be compromised by any normal operation or by any credible accident scenario to the extent that radioactivity is released to the environment during life cycle usage.

From a careful review of literature on previous analyses and tests, the most obvious potential mechan isms for capsule failure have been identified in this document. The materials testing and engineering analyses that pertain to these potential failure mechanisms have been reviewed, evaluated, and summarized. Details of the testing or analys is activities are referenced but not reproduced. No attempt has been made to define potential accident scenarios but rather to examine the ability of the capsules to meet current or considered safety requirements.

\subsection{WASTE MANAGEMENT GOAL}

A Hanford waste management goal has been removal of the long-lived, highheat-producing fission products (cesium-137 and strontium-90) from the highsalt waste liquid and sludges stored in underground tanks. These fission products are purified, converted to a suitable chemical form, encapsulated in high-integrity containers, and stored in water basins pending final disposal. The purpose of this processing is to simplify storage and disposal of the large volume of high-salt waste and to provide additional safety for the storage and eventual disposai of cesium-137 and strontium-90 (Jackson 1977). In meeting this need, the capsules were conservatively designed to exceed the requirements for safe and efficient storage of cesium-137 and strontium-90 in water basins. 
Over the past 15 years, a number of studies have been conducted on salt/container compatibility, salt characterization, capsule behavior under anticipated storage conditions, and capsule integrity. Of particular interest to irradiator use of WESF cesium capsules is a study of a 6-year-old capsule used for 27 months in the Sandia Irradiator for Dried Sewage Solids (SIDSS). This study included evaluation of the salt/stainless steel compatibility, salt and gas composition in the capsules, and mechanical properties of the container material. In addition, a Cesjum Chloride Compatibility Testing Program was started in FY-1982 to obtain compatibility data needed to verify long-term capsule integrity in the anticipated disposal environments. Several capsules have already been examined from this test program, and useful data will continue to be generated. It should be noted that the temperature of the capsules in this test is considerably higher than expected in irradiator applications, but the data are considered valuable to more thoroughly understand the corrosion process. Use of WESF capsules for heat or irradiation sources was not an original design objective but, in terms of safety, many of the requirements for storage and disposal of the cesium chloride capsules are the same as or more severe than the requirements for their use in an irradiator. Thus, the test results are applicable.

\subsection{PREPARATION OF WESF CESIUM CHLORIDE CAPSULES}

Chemical recovery of cesium- 137 and strontium-90 was initiated in the Hanford B-Plant in 1967. Production of capsules began in 1974 in the WESF. Ion-exchange and precipitation processes are used to recover, concentrate, and purify the cesium. After conversion to a chloride solution by the addition of hydrochloric acid to a purified cesium carbonate solution, cesium chloride is evaporated to dryness in air at reduced pressure in a vacuum furnace and then mel ted at 730 to $750^{\circ} \mathrm{C}$. Following venting of the vacuum chamber to the atmosphere, the chamber is tilted and the molten salt is poured into an array of up to seven empty capsules attached to the side wall of the furnace. The furnace geometry and pouring conditions are engineered to fill the capsules to the desired level with molten cesium chloride, but additional salt may be fed into the capsules as it solidifies in the capsules and contracts. 
When cooled, the filled capsules are detached from the furnace, a porous metal disk is placed in each capsule, the cesium chloride and disk are saturated with helium, and the capsule lids are welded in place. Following helium leak testing, the capsules are decontaminated, transferred to a clean cell, and placed inside "outer" containers. The lids are then welded closed, and the first inner capsule weld and both outer capsule welds are ultrasonically examined. Leak testing and ultrasonic examination of capsule welds are discussed in Section 3.4. The completed capsules are then transferred to a water bas in for storage. Capsule details are shown in Figure 1.1. Dimensional tolerances of capsules are discussed more fully in Section 3.3.

The Rockwell Hanford Company has completed the encapsulation of all fission product cesium recovered from high-level wastes produced prior to shutdown of the Purex plant in 1972. The encapsulation campaign extended from September 18, 1974, until 0ctober 31,1983 . Based on calorimetric analys is of each capsule

when filled, $76.7 \times 10^{6} \mathrm{Ci}$ of cesium- 137 have been encapsulated in 1575 capsules. The individual capsules contain from 2 to $75 \mathrm{kCi}$ of cesium when filled, with most of the capsules in the range from 40 to $60 \mathrm{kCi}$.

\subsection{UTILIZATION OF WESF CAPSULES}

In their byproducts plan, the U.S. Department of Energy (DOE) has encouraged the appropriate use of WESF capsules by the staternents . . . "it shall be the policy of the Department of Energy's (DOE) Defense Programs to encourage widespread use of byproducts in meeting unique national needs and in solving societal problems. - DOE, through its contractors, will supply byproduct materials for demonstrations and commercial applications. DOE will accept the return of radioactive materials at the end of their useful life for storage or disposal." (U.S. Department of Energy 1983).

Five cesium isotopes are produced by nuclear fission but only two have any current significance to cesium utilization. Cesium-133 is stable; and cesium- 137 has a half-1ife of 30.2 years, a specific activity of $87 \mathrm{Ci} / \mathrm{g}$ (100\% bas is), and produces $0.42 \mathrm{~W}_{\mathrm{t}}$ per gram (100\% basis). The ${ }^{137} \mathrm{Cs} / \mathrm{Cs}$ ratio is about 0.43 in freshly discharged fuel (Rohrmann 1971; Walker, Kironac, and Rourke 1977). The decay scheme for cesium-137 to stable barium-137 is shown in Figure 1.2 (Peker 1983). 


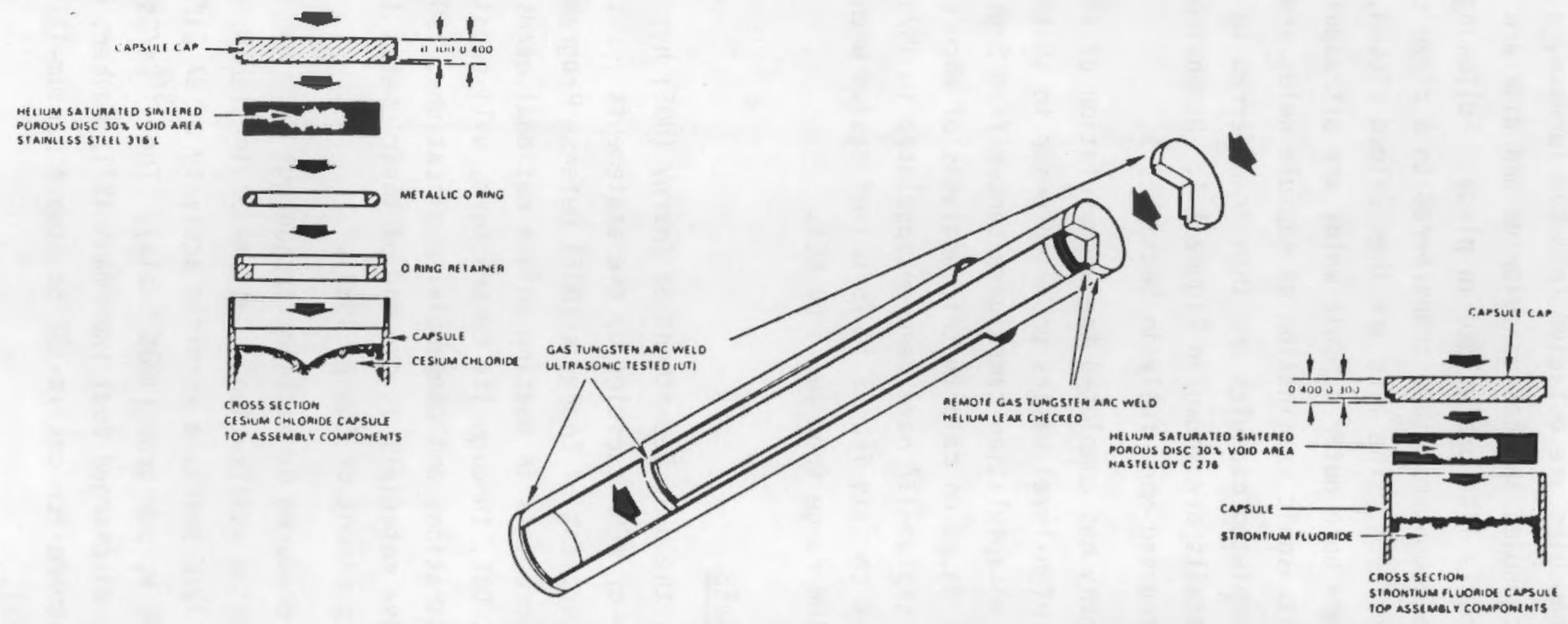

\begin{tabular}{|c|c|c|c|c|c|c|c|c|c|c|}
\hline & \multicolumn{10}{|c|}{ carsule } \\
\hline & & & inNEA & & & & & Oulle & & \\
\hline & Matemiat & {$\left[\begin{array}{l}\text { WhLt } \\
\text { thigkntSS }\end{array}\right.$} & $\begin{array}{l}\text { ou'sior } \\
\text { OAAMEIEn }\end{array}$ & {$\left[\begin{array}{l}\text { TORAL } \\
\text { LeNGIM }\end{array}\right.$} & $\begin{array}{l}\text { TOtAL CA } \\
\text { t }\end{array}$ & mateatal & $\begin{array}{l}\text { WALI } \\
\text { Imickntss }\end{array}$ & $\begin{array}{l}\text { Outsior } \\
\text { oramerta }\end{array}$ & 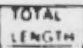 & 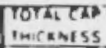 \\
\hline $\begin{array}{l}\text { StRowTIUM } \\
\text { fuORIOOT }\end{array}$ & $\begin{array}{l}\text { masretion } \\
\text { c.270 }\end{array}$ & 0136 & 2260 & $10 \cos n$ & 0400 & $\begin{array}{l}\text { STAMnetss } \\
\text { siffit }\end{array}$ & 0136 & 2025 & 20100 & 0 ond \\
\hline $\begin{array}{l}\text { CISIUM } \\
\text { CMLORIOA }\end{array}$ & $\begin{array}{l}\text { STANLESS } \\
\text { sitEL } \\
3162\end{array}$ & 0 & 2250 & (9, & $0 \times 00$ & $\begin{array}{l}\text { SininLESS } \\
\text { sitEL } \\
3161\end{array}$ & 0136 & 2025 & $20 \mathrm{nts}$ & 0400 \\
\hline
\end{tabular}

ACPEJO3 244

FIGURE 1.1. Detail of WESF Cesium-137 Source Capsule 


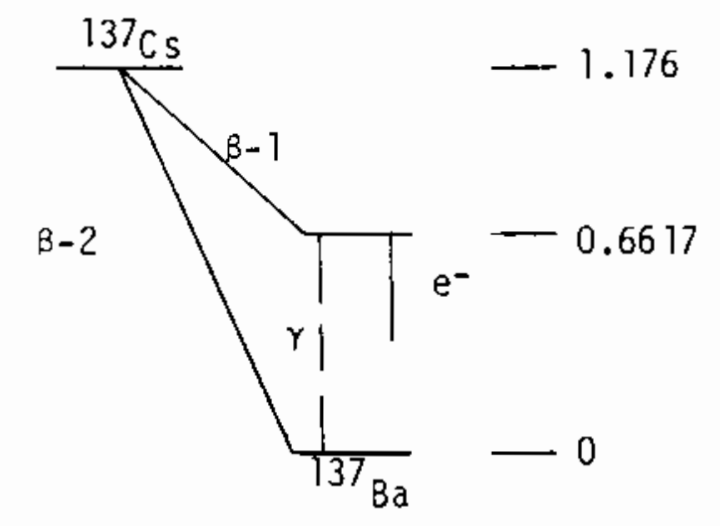

\begin{tabular}{|c|c|c|}
\hline Rad. & $\underline{E(\mathrm{MeV})}$ & $\%$ Abund. \\
\hline$\beta-1$ & 0.5740 & 94.4 \\
\hline$B-2$ & 1.176 & 5.6 \\
\hline $\mathrm{e}^{-}$ & 0.6617 & 9.2 \\
\hline$\gamma$ & 0.6617 & 85.2 \\
\hline
\end{tabular}

FIGURE 1.2. Decay Scheme for Cesium-137 (Peker 1983)

The major use of fission product cesilumill be as a radiation source for sterilizing sewage and disinfesting food products, agricultural products, medical products, and other items. The SIDSS facility has been in operation since 1979 by DOE at the Sandia National Laboratories. The irradiation source is 15 WESF cesium chloride capsules containing about $1 \mathrm{MC} i$ of cesium- 137 at the time of initial operation. Sewage sludge, grapefruit, and mangoes nave been irradiated in the facility (U.S. Department of Energy 1983).

Several commercial irradiators, some using up to $15 \mathrm{MC} i$ of cesium chloride, have been proposed. These commercial facilities will require licensing by the U.S. Nuclear Regulatory Cormission (NRC).

The use of $\mathrm{CsCl}$ capsules in an irradiator will require transfer of the capsules from Hanford to the irradiator in a licensed cask, unloading of the capsules into the irradiator, periodic examination of capsules and facilities, and return to DOE for 41 timate disposal and storage. Irradiators will vary in design; some may load and unload capsules from casks underwater while others may have dry shielded facilities for this purpose. Similarly, some irradiators may store the sources underwater while not being used; others may have dry shielded storage facilities. 
The most realistic utilization period appears to be about one half-life (30 years). The ability of the WESF cesium chloride capsules to withstand thermal, mechanical, and corrosion stresses during both normal use and potential accidents is discussed in Section 3.0 . 


\subsection{CAPSULE PERFORMANCE REQUIREMENTS}

Commercial use of WESF cesium chloride capsules as a gamma radiation source requires that the irradiators that use the sources be licensed. The NRC has not identified specific criteria for registration of large cesium irradiation sources such as the WESF capsule, but the requirements spelled out in the "American National Standard N542; Sealed Radioactive Sources, Classification" (National Bureau of Standards 1978) will presumably play a significant role in the capsule registration process. In keeping with the scope of this document, ANSI N542 has been reviewed and is summarized in this section.

The intent of the American National Standard $N 542$ is stated as follows:

This standard establishes a system of classification of sealed radioactive sources based on performance specifications related to radiation safety. It provides a manufacturer of sealed sources with a series of tests for evaluating the safety of $h$ is product under specified conditions, and also assists a user of such sources to select a type which suits the intended application insofar as maintenance of source integrity is concerned. Tests are prescribed for temperature, external pressure, impact, vibration, and puncture over a $r$ ange of severity. Sealed source performance requirements are identified for a variety of source applications in terms of a specific degree of severity of each test.

Table 2.1 (from ANSI N542 Table 1) sumarizes the various classes of performance tests prescribed in the standard. Table 2.2 (from ANSI N542 Table 4) lists the performance requirements recomended in the standard for typical usage of various types of sealed sources. Four categories of gamma irradiators are defined in Table 2.2.

The standard describes the procedures for determining the classification of a specific sealed radioactive source and the corresponding performance requirements the source must meet. The first step is to establish the radiotoxicity group of the radionuclide in the source. In ANSI N542, Table 2 shows the classifications of the radionuclides according to radiotoxicity and classifies cesium-137 in the Toxicity Group B1. The second step in determining the classification of the source is to determine the amount of activity allowed in 
TABLE 2.1. Classification of Sealed Source Performance Test (National Bureau of Standards 1978)

\begin{tabular}{|c|c|c|c|c|c|c|c|}
\hline \multirow[b]{2}{*}{ Iest } & \multicolumn{7}{|c|}{ Class } \\
\hline & 1 & 2 & 3 & 4 & 5 & 6 & $x$ \\
\hline Temper ature & $\begin{array}{l}\text { No test } \\
\text { required }\end{array}$ & $\begin{array}{l}-40^{\circ} \mathrm{C}(20 \mathrm{~min}) \\
+80^{\circ} \mathrm{C}(1 \mathrm{~h})\end{array}$ & $\begin{array}{l}-40^{\circ} \mathrm{C}(20 \mathrm{~min}) \\
+180^{\circ} \mathrm{C}(1 \mathrm{~h})\end{array}$ & $\begin{array}{l}-40^{\circ} \mathrm{C}(20 \mathrm{~min}) \\
+400^{\circ} \mathrm{C}(1 \mathrm{~h}) \text { and } \\
\text { thermal shock } \\
400^{\circ} \mathrm{C} \text { to } 20^{\circ} \mathrm{C}\end{array}$ & $\begin{array}{l}-40^{\circ} \mathrm{C}(20 \mathrm{~min}) \\
+600^{\circ} \mathrm{C}(1 \mathrm{n}) \text { and } \\
\text { trierma i snock } \\
\text { bu物 } \mathrm{C} \text { to } 20^{\circ} \mathrm{C}\end{array}$ & $\begin{array}{l}-40^{\circ} \mathrm{L}(20 \mathrm{~m}(\mathrm{n}) \\
+80^{\circ} \mathrm{C}(1 \mathrm{n}) \\
\text { therma } \\
800^{\circ} \mathrm{C} \text { to } 20^{\circ} \mathrm{C}\end{array}$ & Special tes $\mathrm{c}$ \\
\hline External Pressure & $\begin{array}{l}\text { No test } \\
\text { required }\end{array}$ & $\begin{array}{l}25 \mathrm{kN} / \mathrm{m}^{2} \mathrm{dbs} \\
(3.6 \mathrm{lb} / \mathrm{in} .2) \\
\text { to atmosphere }\end{array}$ & $\begin{array}{l}25 \mathrm{kN} / \mathrm{m}^{2} \text { abs } \\
\text { to } 2 \mathrm{NN} / \mathrm{m}^{2} \\
(290 \mathrm{lb} / \\
\text { in. } 2) \text { aos }\end{array}$ & $\begin{array}{l}2 b \mathrm{kN} / \mathrm{ml}^{2} \text { dbs } \\
\text { to } 7 \mathrm{MN} / \mathrm{m}^{2} \\
(10 \mathrm{ib} \mathrm{lb} / \\
\text { in. } 2) \text { dus }\end{array}$ & $\begin{array}{l}25 \mathrm{kN} / \mathrm{m}^{2} \text { ads } \\
\text { to } 10 \mathrm{MN} / \mathrm{mr}^{2} \\
(10,103 \mathrm{lo} / \\
\text { in. } 2) \text { ados }\end{array}$ & 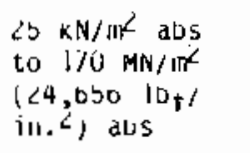 & special test. \\
\hline Impact & No test & $\begin{array}{l}50 \mathrm{~g}(1.802) \\
\text { from } 1 \mathrm{mb}(3.2 \mathrm{~B} \\
\mathrm{ft}) \text { arlid free } \\
\text { drop } 10 \text { times } \\
\text { to a steel } \\
\text { surface from } \\
1.5 \mathrm{~m}(4.92 \mathrm{ft})\end{array}$ & $\begin{array}{l}200 \mathrm{~g}\left(\begin{array}{ll}7 & 0 z\end{array}\right) \\
\text { from } 1\end{array}$ & $\begin{array}{l}2 \mathrm{~kg} \\
\text { froin }\end{array}$ & $\begin{array}{l}b \mathrm{~kg}(11 \mathrm{lb}) \\
\text { from } 1 \mathrm{~m}\end{array}$ & $\begin{array}{l}\angle U \mathrm{~kg}\left(\begin{array}{ll}44 & 10\end{array}\right) \\
\text { troni } 1 \text { 111 }\end{array}$ & special test \\
\hline Vibration & $\begin{array}{l}\text { No test } \\
\text { required }\end{array}$ & $\begin{array}{l}30 \mathrm{~min} ; 25 \text { to } \\
500 \mathrm{~Hz} \text { at } 5-\mathrm{g} \\
\text { Deak amp }\end{array}$ & $\begin{array}{l}30 \mathrm{~min} ; \angle 5 \text { tu } \\
\text { su } \mathrm{Hz} \text { at } 5-\mathrm{g} \\
\text { peak amp and } \\
50 \text { to } 90 \mathrm{~Hz} \\
\text { at } 0.635-\pi m \\
\text { amp peak to } \\
500 \mathrm{~Hz} \text { at } 10 \mathrm{~g}\end{array}$ & $\begin{array}{l}y 0 \mathrm{~min} ; \mathrm{LS} \text { to } \\
80 \mathrm{~Hz} \text { at } 1.5-m ! \\
\text { dmp peak to } \\
\text { peak and } 80 \text { to } \\
2000 \mathrm{~Hz} \text { at } 20 \mathrm{y}\end{array}$ & Not used & wot usea & Specidi lest \\
\hline Puncture & $\begin{array}{l}\text { No test } \\
\text { required }\end{array}$ & $\begin{array}{l}19(15.4 \mathrm{gr}) \\
\text { from } 1 \mathrm{~m}\end{array}$ & $\begin{array}{l}10 g(164 g r) \\
\text { from } 10\end{array}$ & $\begin{array}{l}\text { so g }\left(\begin{array}{ll}1.76 & 0 z\end{array}\right) \\
\text { froin } 1\end{array}$ & $\begin{array}{l}300 \mathrm{~g}\left(\begin{array}{lll}10.0 & 0 z\end{array}\right) \\
\text { from } \mathrm{m}\end{array}$ & $\begin{array}{l}1 \mathrm{~kg}(<. L \mathrm{l}) \\
\text { frum in }\end{array}$ & special test \\
\hline
\end{tabular}


TABLE 2.2. Sealed Source Performance Requirements for Typical Usage (National Bureau of Standards ly/8)

Sealed Source Test and class

Sealed Source Usage

Temperature Pressure Impact Vibration Puncture

Radiography - industrial

Medical

Gamma gauges (medium and high energy)
Unprotected source Source in device

Radiography

Gamma teletherapy

Unprotected source

Source in device

4
4
3
5
4
4

Beta gauges and sources for low energy gamma gauges or $x-r$ ay

fluorescence analysis (excluding gas-filled sources)

0i) well logging

Portable moisture and density gauge (including hand-held or dolly transported)

General neutron source application (excluding reactor startup)

Calibration sources (activity greater than $30 \mathrm{Ci}$ )

Garma irradiators (a)

Ion generators $(b)$

Categories II, III, IV

Category I

Chroma togr aphy

Static eliminators

Smoke detectors

3
3
2
3
3

$\begin{array}{lll}5 & 1 & 5 \\ 3 & 1 & 3 \\ 3 & 1 & 2 \\ 5 & 2 & 4 \\ 3 & 3 & 3 \\ 2 & 3 & 2\end{array}$

3

b

6

\section{2}

2

2

2.

3

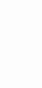

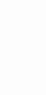


the source. Table 2.3 gives the activity level limits for each radiotoxicity group, as defined in the standard. If the curie content of the source does not exceed the linit defined in Table 2.3, an evaluation of fire, explosion, and corrosion probabilities shall be made. If no significant probability with respect to fire, explosion, and corrosion exists, the required classification for the source (performance requirements) may be taken directly from Table 2.2. If a significant probability exists, then the effects of fire, explosion, and corrosion must be evaluated with particular attention to temperature and impact requirements.

The standard further states that if the curie content of the source exceeds the Timit defined in Table 2.3, as is the case with WESF cesium chloride capsules, an evaluation of fire, explosion, and corrosion probabilities and separate evaluations of the specific source usage and source design shall be made. Thus, in the case with the WESF capsule, a separate detailed evaluation is required to show what classification and performance requirements are needed to register the capsule.

TABLE 2.3. Activity Level Limits (National Bureau of Standards 1978)

Toxicity Group

A

B1

82

C

Leachable(a) Maximum Activity, Ci
and/or Reactive(c) Non Teachabie(b)
and Nonreactive

0.3

3

30

300

300

3000

500

5000

(a) Leachable - greater than 0.1 milligram per gram in $100 \mathrm{ml}$ still $\mathrm{H}_{2} \mathrm{O}$ at $20^{\circ} \mathrm{C}$ in $48 \mathrm{~h}$. In the expression "milligram per gram," the milligram refers to the dissolved or removed radionuclide and the gram to the total weight of radioactive material present, not including the weight of the capsule.

(b) Nonleachable - less than $0.1 \mathrm{milligram}$ per gram in $100 \mathrm{ml}$ still $\mathrm{H}_{2} \mathrm{O}$ at $20^{\circ} \mathrm{C}$ in $48 \mathrm{~h}$.

(c) Reactive - reactive in ordinary atmosphere or water ( $\mathrm{Na}, \mathrm{K}, \mathrm{U}, \mathrm{Cs}$, metals, etc.).

(d) Nonreactive in ordinary atmosphere or water (A1, Au, Co, $\mathrm{Kr}$, ceramics, etc.). 
Two options are defined in the standard for classifying a sealed radioactive source:

1. The classification required for a specific source application can be determined and the source tested to show that it meets the necessary performance tests.

2. The source can be subjected to various performance tests and the classification determined from the test results. Suitable applications can then be selected based on the resulting source classification. Sources of an established classification may be used in any application having less severe specific performance requirements.

The preferred option to be used in registering WESF cesium chloride capsules will depend on the variety of potential applications. The application to the NRC for registration of the WESF cesium chloride capsules for use in irradiators similar to the SIDSS is supported by Sandia National Laboratories document SAND 82-1492 (Kenna 1982). The request proposes, based on ANSI N542, that WESF cesium chloride capsules be registered as Category III gamma irradiator sources that meet either Class 3 or Class 4 performance test requirements, depending on the specific test. As discussed in Section 3.3, the Class 3 and Class 4 performance requirements appear to be adequate for normal operational use in a SIDSS-type facility or as a general-purpose gaima source. The required testing to assure the behavior under accident conditions will depend on the accident scenarios considered viable in each specific irradiator design.

Because of the large curie content of the WESF capsules, ANSI N542 does not define the performance requirements that the capsules must meet for a comercial irradiator. Over the years, many qualification tests have been conducted and nondestructive tests are performed routinely on the WESF capsules including the following: impact (drop), percussion, fire (90 min at $871^{\circ} \mathrm{C}$ ), swelling, burst, mechanical properties of capsule materials, corrosion, salt composition, calorimetry, weld penetration, and leak testing. A more thorough description of the tests and the results obtained are given in Section 3 of this report. 


\subsection{POTENTIAL MECHANISMS FOR RELEASE OF CESIUM-137}

The capsules are designed to contain the radioactive salt under normal operating conditions and all projected accidents. In this section of the report, the mechanisms that could lead to release of salt are evaluated. These mechanisms include corrosion of the capsule container, strain of the capsule walls due to sait expansion at high temperatures, mechanical failure of the container, and fracture of the welds. The following paragraphs treat each of these mechanisms in detail.

\subsection{CAPSULE CORROSION}

In service, the WESF cesium chloride capsules may be subjected to internal corrosion of the inner capsule walls by the contained cesium chloride and impurities and to external corrosion of the outer capsule by the service environment. In addition, corrosion of all capsule surfaces is possible during capsule fabrication and loading. Safety considerations dictate that the capsule material be sufficiently resistant to the various sources of corrosion to ensure adequate containment of the radioactive cesium under all normal conditions and under credible accident conditions. The effects of potential corrosion on the mechanical properties of the inner and outer capsules must be evaluated as they relate to capsule integrity.

\subsubsection{Internal Capsule Corrosion}

The capsule surface exposed to the cesium chloride may be subjected to corrosion by the salt. The metal attack will depend primarily on four factors:

- composition of the salt in the WESF capsule

- metal/cesium chloride interface temperature

- composition and microstructure of the metal

- exposed metal surface-to-cesium chloride volume (S/V) ratio of the capsule.

Other interrelated factors, such as the presence of a lower meiting cesium chloride impurity eutectic, can also affect the rate of metal attack. 


\section{Cesium Chloride Composition}

Thermodynamic considerations indicate that the $316 \mathrm{~L}$ stainiess steel (316L SS) should be resistant to attack by pure cesium chloride at temperatures below the melting point (Fullam 1982). Compatibility data available for CSC1/316L SS confirm this conclusion. WESF-produced cesium chloride, however, contains a number of impurities, some of which can react with components of the stainless steel. The lower the thermodynamic stability of the impurity, the greater the potential reaction with stainless steel.

Information on the impurity content of the cesium chloride produced at WESF is limited to data taken on the cesium feed solution prior to conversion of the carbonate and analys is of the salt from two capsules opened for corrosion analysis (Fullam 1982; Kenna and Schultz 1983). The results of these analyses are shown in Table 3.1. The analys is of the cesium feed solution should be indicative of the impurities; but small amounts of additional contamination and perhaps even some purification could occur during conversion to the chloride, evaporation, and casting. Because of the high radioactivity, cesium chloride analyses are difficult and high precision is not claimed. Fullam (1982) reported wide variability in the analysis for iron and did not report a value. Kenna and Schultz (1983) used spark source mass spectrometry and did not distinguish between barium-137 and cesium-137; the barium-137 is included with the cesium. The capsule was 6 years old, and the barium content would have been about 4 to $5 \mathrm{wt}$. Specification for the WESF feed solution requires that the molar ratio of $\mathrm{Na}+K+\mathrm{Rb}$ to $\mathrm{CS}$ be $\leq 0.15$. If one assumes that the $\mathrm{Na}, \mathrm{K}$, and $\mathrm{Rb}$ are present in equimolar concentrations at the maximum concentrations permitted, the cesium chloride product would contain about $1.6 \mathrm{wt} \% \mathrm{NaCl}, 2.0 \mathrm{wt} \% \mathrm{KCl}$, and $3.3 \mathrm{wt} \% \mathrm{RbCl}$. If sodium were the only alkalj metal impurity in the feed solution, the cesium chloride product could contain a maximum of $4.9 \mathrm{wt} \% \mathrm{NaCl}$ and still meet the specification limit.

Impurities other than alkali metal salts present in the cesium chloride product can come from several sources, including: 
$p h-61)$

TABLE 3.1. Estimates of Impurity Levels in WESF Cesium Chloride. Elements do not equal $100 \%$ because chlorine, oxygen, and perhaps other elements were not included.

\begin{tabular}{|c|c|c|c|}
\hline E lement & Rockwell(a) & Fullam $1982^{\text {(b) }}$ & $\begin{array}{l}\text { Kenna and } \\
\text { Schultz } 1983 \text { (c) }\end{array}$ \\
\hline $\begin{array}{l}\mathrm{A}]^{\star} \\
\mathrm{B}\end{array}$ & 1.7 (d) & $\begin{array}{l}0.14 \\
0.14\end{array}$ & $\begin{array}{l}0.3 \\
0.4\end{array}$ \\
\hline $\mathrm{Ba}$ & 0.94 & 0.55 & - \\
\hline $\mathrm{Ca}$ & 1.0 & -- & 0.05 \\
\hline $\mathrm{Cd}^{\star}$ & -- & 0.02 & -- \\
\hline $\mathrm{Co}^{\star}$ & -- & 0.10 & 0.02 \\
\hline $\mathrm{Cr}^{\star}$ & 0.27 & 1.4 & 0.1 \\
\hline $\mathrm{CS}^{\star}$ & 54.2 & -- & 53.0 \\
\hline $\mathrm{Cu}^{\star}$ & -- & - & 0.2 \\
\hline $\mathrm{Fe}^{*}$ & 0.38 & (e) & 0.5 \\
\hline$k$ & 0.79 & 0.68 & 0.1 \\
\hline $\mathrm{Mg}$ & 0.25 & -- & - \\
\hline$M n^{\star}$ & - & -- & 0.05 \\
\hline $\mathrm{Na}$ & 0.70 & 2.8 & 0.2 \\
\hline$N i \star$ & 0.33 & 0.1 & 0.1 \\
\hline$P \star$ & - & $=-$ & 0.1 \\
\hline $\mathrm{Pb} *$ & 1.4 & 0.14 & -- \\
\hline$P d^{\star}$ & -- & -- & 0.02 \\
\hline RD & 0.52 & -- & 0.02 \\
\hline$S^{\star}$ & - & -- & 5 \\
\hline$S i \star$ & 7.0 & 0.21 & 5 \\
\hline $\mathrm{Sr}^{*}$ & 0.18 & 0.02 & 0.001 \\
\hline$T i^{\star}$ & -- & 0.07 & -- \\
\hline $\mathrm{Zn} *$ & -- & 0.03 & 0.08 \\
\hline
\end{tabular}

(a) The carbonate solution was analyzed by dissolving in nitric acid, diluting, and analyzing by inductively coupled plasma atomic emission spectroscopy. Numbers are averages of several analyses normalized to the chloride form.

(b) The chloride produced at WESF was analyzed as in (a).

(c) The cesium chloride salt from WESF capsule \#C117 was analyzed by spark source mass spectrometry. Ba was not analyzed because $\mathrm{Ba}-137$ was not distinguished from $\mathrm{Cs}-137$ and, therefore, was included with the Cs. The Ba content would have been 6 to 8 wt\%.

(d) Not reported.

(e) Iron $\%$ was very $h i g h$ and nonreproducible, indicating probable contamination of cesium chloride solution.

* Potential metallic barium and cesium oxidizers $\mathrm{Al}$ and $\mathrm{Si}$ were not included because they are most likely in an alumina silicate form and not dispersed homogeneous ly in the salt. 
- inadequate purification of the cesium by ion exchange prior to conversion to the chloride salt

- corrosion of the processing equipment

- carry-over of ion-exchange materials (zeolite) into the WESF operation.

Most of the impurities are expected to be present in the cesium chloride as metal chlorides, except for the ion-exchange materials, which are primarily complex metal oxides (aluminosilicates). During the drying and melting of the cesium chloride, prior to encapsulation, some of the less stable metal chloride impurities could be partially or completely hydrolyzed to metal oxides. Thermodynamic and 1 imited experimental resuits indicate that certain of the less stable chloride and oxide impurities, such as the chlorides of iron and chromium, may attack the $316 \mathrm{~L}$ SS, even when present in low concentrations (Fullam 1982). Additional chemical analyses are currently being conducted on the sait from six WESF capsules. If the actual impurity levels are approximated by the data in Table 3.1 and the impurities appear primarily as metal chlorides, then the impurity content of the cesium chloride could be greater than $10 w t \%$.

Cesium isotopic analyses were performed on a few batches of cesium chloride solution prior to the evaporation, melting, and casting steps. Content net weight and calorimetry were performed on every capsule when the capsules were filled at WESF. Using these data, the weight percent impurity content, determined by difference, was calculated for eight capsules (Table 3.2). In recent months, recalibration of the WESF calorimeter suggests that a correction factor of 0.90 should be applied to previous calorimetry results.

Table 3.2 shows the calculated impurity content of the eight capsules based on original and corrected calorimetry. These calculations suggest the possibility of even tigher impurity content in WESF cesium chloride than shown in Table 3.1 .

In addition to the impurities present initially, the barium concentration will increase with time due to the decay of cesium-137. The chemical form of the barium daughter is unknown because monovalent cesium decays to divalent barium and only one atom of chlorine is available per atom of barium formed. Barium monochloride is known to exist but not at the temperatures encountered in a WESF capsule. If barium monochloride forms initially, it will probably 
TABLE 3.2. Calculated Impurity Content in Eight WESF Cesium Capsules

\begin{tabular}{|c|c|c|c|c|c|c|c|}
\hline $\csc 1$ & & Batch & otopic & Comp. & Capsure & Capsule & $\begin{array}{l}\text { Calculated } \\
\text { Impurity }\end{array}$ \\
\hline $\begin{array}{l}\text { Batch } \\
\text { No. }\end{array}$ & $\begin{array}{l}\text { Capsule } \\
\text { No. }\end{array}$ & $\begin{array}{l}\mathrm{wt \%} \\
137\end{array}$ & $\begin{array}{l}w t \% \\
135 \\
\end{array}$ & $\begin{array}{l}\text { wt\% } \\
133 \\
\end{array}$ & $\begin{array}{c}\text { Calor imetry, } \\
W\end{array}$ & $\begin{array}{c}\text { Contents, } \\
g\end{array}$ & $\begin{array}{c}\text { Content, } \\
\text { wt\% }\end{array}$ \\
\hline
\end{tabular}

Uncorrected Calorimetry

$\begin{array}{llllllll}83-1 & C 1511 & 33.13 & 13.67 & 53.2 & 257.7 & 2,639 & 11 \\ 83-1 & \text { C 1512 } & 33.13 & 13.67 & 53.2 & 244.5 & 2,651 & 16 \\ 82-6 & \text { C1411 } & 32.79 & 13.82 & 53.37 & 154.6 & 1,650 & 14 \\ 82-6 & \text { C1414 } & 32.79 & 13.82 & 53.37 & 250.0 & 2,686 & 14 \\ 81-57 & C 1216 & 33.40 & 14.15 & 52.45 & 255.6 & 2,983 & 23 \\ 81-57 & C 1226 & 33.40 & 14.15 & 52.45 & 262.7 & 2,980 & 20 \\ 79-9(a) & C 540 & 33.69 & 12.68 & 53.63 & 262.3 & 2,558 & 8 \\ 79-9 & C 530 & 33.69 & 12.68 & 53.63 & 290.9 & 2,948 & 12 .\end{array}$

Corrected Calorimetry

$\begin{array}{llllllll}83-1 & C 1511 & 33.13 & 13.67 & 53.2 & 230.9 & 2,639 & 21 \\ 83-1 & C 1512 & 33.13 & 13.67 & 53.2 & 219.1 & 2,651 & 25 \\ 82-6 & C 1411 & 32.79 & 13.82 & 53.37 & 138.5 & 1,650 & 23 \\ 82-6 & C 1414 & 32.79 & 13.82 & 53.37 & 224.0 & 2,686 & 24 \\ 81-57 & C 1216 & 33.40 & 14.15 & 52.45 & 229.03 & 2,983 & 31 \\ 81-57 & C 1226 & 33.40 & 14.15 & 52.45 & 235.4 & 2,980 & 29 \\ 79-9(a) & C 540 & 33.69 & 12.68 & 53.63 & 235.0 & 2,558 & 18 \\ 79-9 & C 530 & 33.69 & 12.68 & 53.63 & 260.7 & 2,948 & 21\end{array}$

(a) Records do not unequivocally identify the isotope analys is to Batch 79-9. The date of the analys is corresponded to the date Batch 79-9 was processed.

disproportionate yielding $\mathrm{BaCl}_{2}$ and metallic Ba to satisfy all the valences. Further reactions of the chemically reactive metallic barium with the impurities will probably occur. Thermodynamic data indicate that metallic barium would reduce $\mathrm{CsCl}$ to yield metallic cesium and $\mathrm{BaCl}_{2}$ only at high temperatures. However, both metallic barium and cesium will reduce the less-stable impurity cations to lower oxidation states with the formation of the more 
stable barium or cesium compounds (see Table 3.6). These metallic barium and cesium reactions appear to be beneficial from two points of view: 1) the highly reactive metallic barium would be converted to more stable species and 2) the concentration of potentially corrosive impurities would be reduced.

Further evidence supporting the absence of metallic barium or cesium was obtained during March 1984 when 27 WESF cesium chloride capsules were cut open and the contents dissolved by immersing in water. There was no bubbling or any indication of gas formation. Calculations indicate that the decay of cesium-137 would have produced up to $70 \mathrm{~g}$ of barium per capsule. If such amounts of barium or cesium had been present as metal, large amounts of hydrogen gas would have been generated by reaction of the metal with water. The absence of evolution of gas confirms that, at least in these capsules, no metallic barium or cesium was present. A similar observation was also made on 18 of 20 additional capsules that were recently opened and the salt dissolved. On two of the capsules, however, there was some evidence of a relatively sinall amount of gas generation upon dissolution, which may indicate that a small fraction of the sait remains in a chemically reactive form in isolated capsules.

Anionic impurities such as oxides or carbonates may also be present as a result of incomplete neutralization of the cesium carbonate. These impurities also have the potential to react with $316 \mathrm{~L}$ SS. WESF quality control standards minimize the concentration of these species, however.

In addition to the high impurity content of the capsules, the impurity content of the chloride can vary substantially from batch to batch. Therefore, WESF capsules that are subjected to identical conditions may exhibit some differences in metal attack.

Pure cesium chloride melts at $645^{\circ} \mathrm{C}$, but the addition of impurity chlorides to the cesium chloride can result in the formation of lower melting phases. Table 3.3 lists the minimum meiting points observed with certain metal chloride mixtures (Fullam 1982). The amount of melting depends on the relative amounts of the impurities in the mixture. A phase diagram of the WESF cesium chloride mixture would be very complex, but the melting point data in Table 3.3 indicate that some melting may occur below $500^{\circ} \mathrm{C}$. The presence of low melting phases in the WESF cesium chloride could produce an increased 
TABLE 3.3. Minimum Melting Points Observed in Certain Metal Chloride Systems (Fullam 1982)

\begin{tabular}{|c|c|c|c|}
\hline Sys tem & $\begin{array}{l}\text { Minimum Melting } \\
\text { Point, }{ }^{\circ} \mathrm{C} \\
\end{array}$ & System & $\begin{array}{l}\text { Minimum MeIting } \\
\text { Point, }{ }^{\circ} \mathrm{C}\end{array}$ \\
\hline CsCl-KCl & 605 & {$[\mathrm{sc} 1-\mathrm{FeC}]_{3}$} & 270 \\
\hline $\mathrm{CsC} 1-\mathrm{NaCl}$ & 493 & $\mathrm{CsCl}-\mathrm{MnCl}_{2}$ & 489 \\
\hline $\mathrm{CsCl}^{-\mathrm{BaCl}_{2}}$ & 557 & $\mathrm{CsCl-NiC} 1_{2}$ & 520 \\
\hline $\mathrm{CsC1}-\mathrm{CrCl}_{3}$ & 622 & $\mathrm{CsCl}-\mathrm{NaC} 1-\mathrm{KCl}$ & 478 \\
\hline
\end{tabular}

corrosion rate at the cesium chloride/stainless steel interface at temperatures above their melting point because a liquid-solid reaction often proceeds at a greater rate than a solid-solid reaction. The presence of a liquid phase could also allow impurities in the bulk of the cesium chloride to diffuse more rapidiy to the interface than if solid-solid diffusion was the only transport mechanism available. It should be noted that the amount of liquid phase in the salt is dependent upon the composition and is expected to be very small $(<1 \%)$ in the WESF mixture.

If impurities in the cesium chloride are the principal cause of metal attack, the extent of the attack will be 1 imited by the amount of impurities available. The rate will, thus, be expected to be high initially but fall off as the reactive impurities are consumed. Thus, the total corrosion at long times would also depend on the total impurities as well as exposure time and temperature. The data available on cesium chloride/316L SS compatibility tend to confirm this postulate.

\section{Cesium Chloride/Stainless Steel Compatibility Studies}

The initial cesium chloride/316L SS compatibility studies carried out at PNL as part of the WESF development program used a relatively pure cesium chloride (Fullam 1972). Results indicated that $316 \mathrm{~L} 55$ was quite resistant to attack by chloride at temperatures of $400^{\circ} \mathrm{C}$ and $600^{\circ} \mathrm{C}$. With nonradioactive cesium chloride, the corrosion depth in the $316 \mathrm{~L}$ SS was 0.001 in. or less at $400^{\circ} \mathrm{C}$ and 0.002 in. or less at $600^{\circ} \mathrm{C}$ after 3 years exposure. Adding barium chloride did not affect the extent of corrosion in either case. With radioactive cesium chloride, the corrosion depth was $0.001 \mathrm{in.}$ or less at $400^{\circ} \mathrm{C}$ after 1 year exposure. 


\section{Examination of Capsule Used in SIDSS Facility}

An aged WESF cesium chloride capsule that had been used in the SIDSS facility was subjected to destructive examination (Kenna and Schultz 1983). The capsule was 6 years old at the time it was sectioned at the 0ak Ridge National Laboratory (ORNL) and had been in service in the SIOSS facility for about 27 months. Although the thermal $h$ istory of the capsule while in the SIOSS facility is not known in detail, the outer wall temperature of the capsules in the irradiator was 80 to $130^{\circ} \mathrm{C}$. The interface temperature between the salt and the inner capsule wall has been calculated as less than $50^{\circ} \mathrm{C}$ greater than the outer wall temperature, indicating a salt/stainless steel interface temperature of $180^{\circ} \mathrm{C}$ or less. The sectioned inner capsule was subjected to metallographic examination, electron microprobe analysis, and scanning electron microscopy to determine the extent of metal attack by the cesium chloride. Longitudinal tensile tests were carried out on specimens cut from the inner and outer capsules. Results of the tensile tests are discussed in Section 4.3.

Maximum corrosion of the inner capsule by the cesium chloride, as determined from photomicrographs, was reported to be $0.003 \mathrm{in.;}$ however, that number was a typographical error and the maximum corrosion was actually about $0.0003 \mathrm{in}$. Kenna and Schultz (1983) assumed that no general thinning of the wall had occurred. This assumption would appear to be justified since the mechan ism for corrosion seems to be pitting rather than general dissolution of the entire surface. Kenna and Schultz (1983) also observed that machining marks remained on the inside wall of the capsule. It is interesting to note that the corrosion observed in the 6-year-old SIDSS capsule was no greater than the corrosion observed in newly filled capsules (Bryan 1983).

The initial SIDSS loading in 1979 included 15 WESF-type capsules. Two additional capsules from this group were recently returned to Hanford for examination. This examination will supply data on corrosion in a dry irradiator environment after 5 years, salt composition, and container mechanical properties. It is expected that capsules from the SIDSS facility will be examined periodically for several years to confirm their integrity in that irradiator application. 


\section{High-Temperature Geologic Disposal Studies}

In the Cesium Chioride Compatibility Testing Program now under way at PNL (Fullam 1982; Bryan 1983), the wall thicknesses of eight "inner" capsules were measured at $n$ ine defined locations down the length of each capsule and at $n$ ine locations diametrically opposite each initial location. The capsules were filled with typical production cesium chloride. Six capsules were processed through all steps of the double encapsulation process; each was insulated in a vertical position and allowed to self-heat.

Periodic temperature measurements were taken at six locations down the outside wall of the outer capsule to establish a capsule temperature profile as a function of time. The plan was to age the capsules at a cesium chloride/316L SS interface temperature of $450^{\circ} \mathrm{C}$ and then, one by one, remove capsules after $2,200,4,400,8,400,16,000,24,000$, and $32,000 \mathrm{~h}$ of aging and evaluate the corrosion at each of the premeasured locations. The temperature of these capsules was selected as the maximum anticipated during geologic disposal. Although this temperature is 200 to $250^{\circ} \mathrm{C}$ above that expected in an irradiator application, the data are reported to help understand the corrosion mechanisms and the effect of temperature on corrosion. These data are also useful in evaluating the effect of WESF capsule impurity on corrosion by comparing them with the initial high-temperature compatibility data (Fullam 1972). Furthermore, this study is the most carefuliy controlled of any conducted on WESF capsules.

The first three capsules have been removed as planned and shipped by cask to ORNL for opening, sectioning, and metallographic examination. Some minor temperature variations were observed in the capsules with time, but the average temperature was nearly as desired. The temperature of the $316 \mathrm{~L}$ SS/ cesium chloride interface was calculated from temperature measurements on the outer wall. The interface temperature varies from about $400^{\circ} \mathrm{C}$ near the bottom, to $460^{\circ} \mathrm{C}$ just below the capsule midpoint, then to $360^{\circ} \mathrm{C}$ near the top of the capsule. A control test was established by carefully measuring and characterizing test coupons of $316 \mathrm{~L}$ SS and heating them in argon at $400^{\circ} \mathrm{C}$, $450^{\circ} \mathrm{C}$, and $500^{\circ} \mathrm{C}$ for the same time periods as the filled capsules. 
Two inner capsules were filled with cesium chloride but not encapsulated. The sait was dissolved from these two "zero-time" capsules so that corrosion caused by the melt casting operations could be evaluated. Metallographic examination of samples taken from the two zero-time capsules indicates that filling the capsules with molten cesium chloride produced relatively little attack on the $316 \mathrm{~L}$ SS $(\leq 0.001 \mathrm{in.})$. The attack was somewhat greater in the upper part of the capsules and appeared to involve general surface dissolution with some limited grain boundary attack.

Capsules aged at $450^{\circ} \mathrm{C}$ for 2208,4392 , and $8784 \mathrm{~h}$ were removed from the insulation and shipped to ORNL for examination. The capsules were sectioned; the salt was removed; and the sections were mounted, polished, etched, and photographed. These initial results (Table 3.4) indicate much greater metal attack than was observed in Fullam's earlier tests with pure cesium chloride (Bryan 1983). Intergranular attack was not observed in the capsule tested for $2208 \mathrm{~h}$ but was extensive in the 4392- $h$ capsule. The greater attack observed with standard WESF cesium chloride compared with the attack by pure cesium chloride used in earlier tests is probabiy due to the greater concentration of impurities in WESF material. The lower corrosion rate observed in the capsule heated for $8784 \mathrm{~h}$ suggests a lower impurity content in the salt from this capsule than that in the two capsules tested for shorter times. In no case was the maximum attack observed in the section of maximum temperature, indicating that the total corrosion at any given time is controlled by impurity content as well as temperature.

In an attempt to assess the accuracy of the corrosion rates observed by the metallographic technique, sample thicknesses determined metallographically were compared with the initial thicknesses measured ultrasonically prior to capsule assembly. Measurements of the sample thicknesses of the polished section with an optical grid invariably yielded a thickness slightly greater than the initial wall thickness. The thickness of the polished sections would be increased by any deviation from vertical in the potting matrix. A deviation of $20^{\circ}$ from vertical would produce an error of $0.009 \mathrm{in}$. in measuring a 0.140-in. thick section and would explain the increased wall thickness tnat was observed. Since the $20^{\circ}$ angle would appear to be larger than expected, 
TABLE 3.4. Estimated Metal Attack in Thermally Aged WESF Cesium Chloride Capsules

\begin{tabular}{|c|c|c|c|c|c|c|c|c|}
\hline \multirow[b]{3}{*}{ Exposure, $h$} & \multicolumn{8}{|c|}{ Distance from } \\
\hline & $4 . \overline{3}$ & in. & 8.3 & & 13.4 & in. & 77.4 & in. \\
\hline & $\begin{array}{l}\text { Average } \\
\text { Temp., }{ }^{\circ} \mathrm{C}\end{array}$ & $\begin{array}{c}\text { Attack, } \\
\text { in. }\end{array}$ & $\begin{array}{l}\text { Average } \\
\text { Temp., }{ }^{\circ} \mathrm{C}\end{array}$ & $\begin{array}{l}\text { Attack, } \\
\text { in. }\end{array}$ & $\begin{array}{l}\text { Average } \\
\text { Jemp., }{ }^{\circ} \mathrm{C}\end{array}$ & $\begin{array}{l}\text { Attack, } \\
\text { in. }\end{array}$ & $\begin{array}{l}\text { Average } \\
\text { Temp., }{ }^{\circ} \mathrm{C}\end{array}$ & $\begin{array}{l}\text { Attack, } \\
\text { in. }\end{array}$ \\
\hline 2208 & 415 & 0.0024 & 455 & 0.0012 & 420 & 0.0012 & 354 & 0.0014 \\
\hline 4392 & 430 & 0.0043 & 449 & 0.0032 & 400 & 0.0034 & 350 & 0.0020 \\
\hline 8784 & 432 & 0.0012 & 460 & 0.0008 & 415 & 0.0024 & 356 & 0.0008 \\
\hline
\end{tabular}


the additional increase from the initial wall thickness is probably due to small differences in the techniques used to make the measurements. The reported corrosion rates are, thus, those determined from the depth of the valleys in the photomicrograph relative to the ridges. Since there is little evidence for generalized corrosion and in no case was the measured sample thickness significantly less than the initial thickness, the corrosion rate measured by this method is considered to be a valid measure of the total corrosion of the stainless steel. A longer corrosion test is under way that will yield more data and permit a more quantitative assessment of the compatibility of WESF-type salt with the stainless steel container.

Experimental data on the pure cesium chloride/stainless steel interaction have shown that little corrosion occurs up to temperatures of $600^{\circ} \mathrm{C}$ (Fullam 1972). However, thermodynamic data show the potential for reaction of the stainless steel container with some of the impurities present in the salt. Significant interaction was observed in actual capsules held at $450^{\circ} \mathrm{C}$. The comparison of the studies with pure cesium chloride and actual WESF capsules clearly shows that the major corrosion is due to impurities in the salt. At Tower temperatures, however, the corrosion rate is still very small as shown from examination of a WESF capsule held at 150 to $180^{\circ} \mathrm{C}$ in the SIDSS facility for 27 months after storage for 4 years in the WESF water pool. Since data at typical irradiator capsule temperatures indicate that corrosion rates would be very low, corrosion does not appear to be of concern for projected irradiator applications.

Tests to supplement the data are continuing with periodic examination of capsules from the SIDSS facility, several capsules from the WESF pool, and capsules for geologic disposal studies at $450^{\circ} \mathrm{C}$ interface temperatures. These tests will supplement the statistical data currently available and will resolve the uncertainties in the data generated thus far.

\section{Metal/Ces ium Chloride Interface Temperature}

The service temperature of the WESF cesium chloride capsules will affect the rate of metal attack by the cesium chloride (and contained impurities) and could possibly affect the reaction mechanisms involved. In general, the higher the metal/salt interface temperature, the higher the corrosion rate. 
In addition, the nigher the temperature, the more types of impurities that could be invoived in the metal attack.

Depending on the irradiator design, a significant temperature graoient could exist along the length of and/or around the circumference of the capsule. This temperature gradient couid resuit in nonuniform attack of the capsule surface exposed to the ceslum cnloride. In actual service, the capsule retailcesium chioride interiace temperature must be linited to a levei such that any metal corrosion opserved will not affect the structural integrity of the eapsula.

if the capsules were subjected to mucn nigner than norma $i$ tenperacures during potentlal accident conditions, larger corrosion rates would be expectad. For exampie, a standarg accident scenerio for seaied sources is exposure to an $300^{\circ} \mathrm{r}$ fire for 30 to $60 \mathrm{mtn}$. If the capsute reached temperatures aporoacring $800^{\circ} \mathrm{C}$ during this exposure, the cesiun chioride in the inner capsule wouid be molten. The best data avallabie to assess the effect of suen a temperature cone from the disf operation where the capsule is filleo by pouring moiten cesium chloride into the capsule (see Section 3.1.3). Corra. ston of the capsuie due to the flling anounts to about 0.00 in. A] thougn the two scenarios are not completely andiogous, the data ootained from the filing operation indicate that exposing tne capsule to $800^{\circ} \mathrm{C}$ for 30 to 60 min woulo not resuit in excessive corrosion. Renoving capsules that have been suejected to an $800^{\circ} \mathrm{C}$ fire from service shoulo je considered.

\section{Metal Mieros tructure}

Corrosion of the $316 \mathrm{~L}$ SS by the HESF cesium cnioride (and contained impurtties) will prooably involve some form of grain boundary attack. Capsule service temperatures that produce additional grain ooundary precipitates in the metal tneraase the rate and extent of the grain ooundary attacx. Al though the low carbon content of the $316 \mathrm{~L}$. SS is intended to reduce intergranular preclpitation, it does not completely prevent it at elevated temperatures. Aging tes is at PNL with $316 \mathrm{~L}$ SS show that some intergranular precipitation occurs when the dioy is held at $500^{\circ} \mathrm{C}$ for extended periods of time, but intergranuar preetpitation was not observed at $450^{\circ} \mathrm{C}$. 


\subsubsection{External Capsule Corrosion}

The environments and temperature regimes that the WESF cesium capsules could encounter $w i l l$ depend on the irradiator design. It is expected that irradiation will occur in air and that the capsules wili be stored in either air or water when out of service for storage or maintenance. Since the system would be designed to control the capsule temperature and since 316L SS is quite resistant to air oxidation, it is extremely unlikely that the outer capsule surface temperature would be high enough during normal service for air oxidation of the stainless steel to become a problem. Furthermore, air oxidation of $316 \mathrm{~L}$ SS at $800^{\circ} \mathrm{C}$ for less than $1 \mathrm{~h}$ in a postulated accident scenario would not be sufficient to adversely affect the integrity of the capsule.

\subsubsection{Corrosion During Capsule Preparation}

Corrosion of capsule components during fabrication is not considered to be a problem. Molten cesium chloride is poured into the inner capsule and che salt is allowed to solidify. Two capsules were examined that showed a small but measurable attack of the $316 \mathrm{~L}$ SS during the filling operation. The maximum attack observed was about 0.001 in. (Bryan 1983).

Another instance of corrosive attack during capsule preparation was recently observed (Bryan 1983). Examination of the inner capsule showed that the outer surfaces of the capsules were discolored and pitted in several places. Photomicrographs of the affected areas showed that extensive pitting had occurred and that second phases had formed in most of the affected areas. The maximum attack observed was about 0.012 in., which corresponds to about $y \%$ of the initial capsule wall thickness. This attack was also observed on a second capsule, but the affected areas did not appear to be as extensive. Additional investigation of the problem indicated that the corrosion was probably caused by the electropolishing operation used to decontaminate the surface of the capsule before it was loaded into the outer capsule. If this is the mechanism of the attack, no further corrosion would be expected. Work is under way to determine the cause of the corrosion and what effect it might have on the integrity of the capsule. Although the observed corrosion was localized, the pitting regions could serve as points for crack propagation if the inner capsule were highiy stressed. 


\subsection{THERMAL EXPANSION}

When the temperature of a capsule is increased, both the capsule and its contents will expand. At normal operating temperatures of a WESF cesium chloride capsule, the salt volume will be considerably less than the volume of the capsule. At higher temperatures, however, capsule expansion due to stresses by the salt may occur. Therefore, the effect of a temperature rise to $800^{\circ} \mathrm{C}$ on the capsules has been evaluated.

\subsubsection{Effects of Cesium Chloride Phase Transformations and Thermal Expansion}

As discussed in the Introduction, the WESF capsules were filled by pouring molten cesium chloride into the capsule inner container and cooled in the tilt position. In this process, additional molten material can be added to the capsule as the salt cools and contracts until the salt in the filler tube solidifies. Upon further cooling, the salt contracts, leaving a relatively large free volume in the top of the capsule and a substantial pore volume with in the cast cesium chloride cylinder. This contraction is due to the transformation from liquid to solid and a solid-solid transition at a lower temperature. Table 3.5 shows the $\mathrm{CsCl}$ density as a function of temperature; associated with the bcc to fcc transition is a $15 \%$ decrease in density and a 9\% decrease with the fcc to liquid transition. During filling, one could visualize a process where liquid cesium chloride not only filled the space made available by transformation from liquid to fcc but also filled some of the space made available by transformation from fcc to bcc. However, Honeyman (1980) reported that they were not able to fill a capsule to more than $79 \%$ of theoretical density by cooling and filling the voids with mol ten material. This resistance to overfilling is apparently a result of a slow rate of transformation from fCc to bcc and a boundary layer of the higher volume solid fcc that is not penetrated by the molten salt. In spite of this resistance, some of the WESF capsules contain sufficient salt so that the volume of the salt will exceed the initial capsule volume when heated to $800^{\circ} \mathrm{C}$.

The cesium chloride content in WESF capsules ranges from 1286 to $3247 \mathrm{~g}$, resuiting in loading factors (content mass per inner capsule volume) of $1.36 \pm 0.05$ to $3.45 \pm 0.11 \mathrm{~g} / \mathrm{cm}^{3}$ at room temperature and $1.31 \pm 0.04$ to 
Table 3.5. Density and Phase Changes of Pure(a) WESF CsC l with Changes in Temperature (Adapted from Rimshaw and Ketchen 1967)

\begin{tabular}{|c|c|c|c|}
\hline \multirow{2}{*}{$\begin{array}{c}\text { Temper ature, } \\
{ }^{\circ} \mathrm{C}\end{array}$} & \multicolumn{3}{|c|}{ Dens ity, $\mathrm{g} / \mathrm{cm}^{3}$} \\
\hline & bcc & $\mathrm{fcC}$ & Liquid \\
\hline 25 & 4.04 & & \\
\hline 100 & 3.99 & & \\
\hline 200 & 3.93 & & \\
\hline 300 & 3.86 & & \\
\hline 400 & 3.79 & & \\
\hline 469 & $3.74(b)$ & 3.18 & \\
\hline 500 & & 3.17 & \\
\hline 600 & & 3.12 & \\
\hline 645 & & $3.10(b)$ & 2.82 \\
\hline 700 & & & 2.76 \\
\hline 800 & & & 2.65 \\
\hline 900 & & & 2.54 \\
\hline 1000 & & & 2.44 \\
\hline
\end{tabular}

(a) Assumes a ${ }^{137} \mathrm{Cs} / \mathrm{Cs}$ compos ition ratio of 0.4 and no other compounds present except cesium chloride.

(b) The density decreases by $15 \%$ during transformation from bcc to fcc and by $9 \%$ during melting.

$3.30 \pm 0.1 \mathrm{~g} / \mathrm{cm}^{3}$ at $800^{\circ} \mathrm{C}$. The loading factor decreases with increasing temperature due to the thermal expansion of the capsule, which has a linear therma] expansion coefficient of $1.89 \times 10^{-5} \mathrm{~cm} / \mathrm{cm}-{ }^{\circ} \mathrm{C}$ (Allegheny 1959). The capsules also contain a small amount of gas. The gas from a 6-year-old capsule was analyzed and was found to contain $56 \mathrm{~cm}^{3}$ (STP); $99.8 \mathrm{~mol} \%$ of which was $\mathrm{He}, \mathrm{N}_{2}$, $\mathrm{CO}$, and $\mathrm{Ar}$ and 0.12 mol\% of which was $\mathrm{H}_{2} \mathrm{O}$ (Kenna and Schultz 1983).

The density of WESF cesium chloride, assumed to be the density of pure cesium chloride with a small correction for the higher cesium-137 content, is shown in Table 3.5 as a function of temperature and material state. A WESF capsule with a loading factor of $2.77 \mathrm{~g} / \mathrm{cm}^{3}$ at $25^{\circ} \mathrm{C}$ would be completely filled at $800^{\circ} \mathrm{C}$ where the cesium chloride density is $2.65 \mathrm{~g} / \mathrm{cm}^{3}$. Thus, any capsule with a lower loading factor could be heated to $800^{\circ} \mathrm{C}$ without straining the inner capsule wall, but higher loading factors would require expansion of the inner capsule wall to accommodate the salt volume. The extent and consequences of this expansion are discussed further in Section 3.2.3. In the 
evaluation, the $6-\mathrm{cm}^{3}$ volume with in the sintered disk was assumed to contain the gas with a resulting pressure of less than 34 atm $\left(500\right.$ psi) at $800^{\circ} \mathrm{C}$.

\subsubsection{Effects of Decay Products and Impurities}

The actual density of capsule contents will vary somewhat from the values of Table 3.5, depending on the initial impurity content and on the formation of barium compounds during radioactive decay. Radioactive decay of ${ }^{137} \mathrm{CsCl}$ results in the formation of ${ }^{137} \mathrm{BaCl}$, which is expected to disproportionate into $\mathrm{Ba}+\mathrm{BaCl}_{2}$ unless other impurities are present that can react with the metallic barium. In the case of the WESF cesium chloride, the sustained presence of free barium is not expected because barium will readily reduce many of the expected contaminants contained in the capsule. This is illustrated by the data in Table 3.6, which shows reactions of barium with iron contaminants, the free energies of reaction, change in molar volume, and weight percent contaminants needed to react with all of the barium produced in the first 30 years.

It is recognized that all capsule contaminants are not iron compounds; iron is used only to illustrate the effect of contaminants on volume of capsule contents. In general, the volume of capsule contents at $800^{\circ} \mathrm{C}$ will decrease with radioactive decay if the barium produced by reaction (1) reduces the contaminants by reactions such as (3) to (6). The presence of contaminants and composition of the WESF salt are discussed more fully in Section 3.1 . As seen in Table 3.6, barium reduces cesium chloride by reaction (2) at high temperatures. The equilibrium of reaction (2) tends to increasingiy favor cesium with increased temperature, i.e., at $25^{\circ} \mathrm{C}$ barium is preferred but at $800^{\circ} \mathrm{C}$ cesium is preferred. If significant metallic cesium were formed, it would also be oxidized by contaminant compounds in the capsule. Further evidence against the formation of metallic barium or cesium was the finding by Kenna and Shultz (1983) that water vapor was present in the capsule gas of the 6-year-old cesium chloride capsule used in the SIDSS facility and destructively examined at ORNL.

A quantitative evaluation of the density of capsule contents as a function of decay time would require more knowledge of the composition of WESF salt than is currently avaijable plus thermal expansion and density data on 
TABLE 3.6. Effect of Iron Contaminants on the Volume of Aged ${ }^{137} \mathrm{CSC} 1$ Contents with Reactions and Free Energies of Formation Given(a)

$\Delta G, \mathrm{k} \mathrm{Cal/mole} \mathrm{Ba}$ Change in Molar $25^{\circ} \mathrm{C} \quad$ Volume at $800^{\circ} \mathrm{C}$, wt\% Element

Barium Produced by Radioactive Decay $\underline{25^{\circ} \mathrm{C}} \quad \underline{800^{\circ} \mathrm{C}}$ $\mathrm{cm}^{3} / \mathrm{mole}^{\mathrm{Ba}}$ Needed in $30 \mathrm{yr}$

1. $2\left({ }^{137} \mathrm{CsCl}\right)-\gamma \rightarrow 137 \mathrm{BaCl}_{2}+137 \mathrm{Ba}$ $-23.9$

Expected Reaction of Barium with No Contaminants

2. $2 \mathrm{CsCl}+\mathrm{Ba} \rightarrow 8 \mathrm{aCl}_{2}+2 \mathrm{Cs}$

4.7 $-3.1$

78.7

Expected Reactions of Barium with

Iron Contaminants

3. $\mathrm{FeCl}_{2}+\mathrm{Ba} \rightarrow \mathrm{BaCl}_{2}+\mathrm{Fe}$

$-122$

$-18.9$

2.2

4. $2 / 3 \mathrm{CrCl}_{3}+\mathrm{Ba} \rightarrow \mathrm{BaCl}_{2}+2 / 3 \mathrm{Cr}$

$-116$

$-19.4$

1.4

5. $\mathrm{NiCl}_{2}+\mathrm{Ba} \rightarrow \mathrm{BaCl}_{2}+\mathrm{Ni}$

$-132$

$-15.8$

2.4

6. $\mathrm{PbCl}_{2}+\mathrm{Ba} \rightarrow \mathrm{BaCl}_{2}+\mathrm{Pb}$

$-119$

7. $1 / 2 \mathrm{SiO}_{2}+\mathrm{Ba} \rightarrow \mathrm{BaO}+1 / 2 \mathrm{Si}$

$-24$

$-15.2$

8.3

8. $1 / 3 \mathrm{Al}_{2} \mathrm{O}_{3}+\mathrm{Ba} \rightarrow \mathrm{BaO}+2 / 3 \mathrm{Al}$

0.6

$-20.2$

0.6

$-14.8$

0.7

(a) In a 2800-g capsule -1.6 moles of free barium would be produced in 30 years by reaction (1). 
the mixed salts in aged capsules. It would appear, however, that the actual density of contents of the aged WESF capsules would be greater at temperatures above $645^{\circ} \mathrm{C}$ than the densities of pure cesium chloride shown in Tabie 3.5 . Thus, smaller salt volumes would also result.

\subsubsection{Volume of WESF Inner Capsules and the Annular Volume Between Inner and Outer Capsules}

The volumes of WESF inner capsules fall into three ranges as shown in Table 3.7. The newest capsules have less volume than the older ones because of an increased inner capsule wall thickness. The newest group constitutes the largest number of WESF capsules. The annular space between the inner and outer capsules defines the volume expansion of the inner capsule before it begins to expand the outer capsule. The end space in the capsules is not included because the inner capsuie tends to increase in diameter rather than length as it expands. Any increase in length would produce a volume increase not accounted for in our analyses.

\subsubsection{Accommodation of Cesium Chloride in WESF Capsules at Elevated Temperatures}

As the temperature is increased, cesium chloride expands into the free volume with in the capsule as depicted by Figure 3.1. In addition to the linear coefficient of expansion, cesium chloride also greatly expands during the two phase changes shown in the figure and indicated in Table 3.4. In the example shown, at about $700^{\circ} \mathrm{C}$, the free volume of the inner capsule has been completely occupied by the expanding cesium chloride. With a further increase in temperature, the inner capsule wall must expand to accomodate the salt volume. As the inner capsule expands, the annular volume between the inner and outer capsule walls decreases. In the example shown in Figure 3.1, however, it does not diminish to zero even at $1000^{\circ} \mathrm{C}$. Figure 3.1 also illustrates the expected effect of isotope decay on the expansion of the capsule contents. At temperatures above the melting point, the volume of the salt in the aged capsule is expected to be smaller than in the unaged capsule, resulting in decreased expansion of the inner capsule.

Yielding of the inner capsule wall has been observed during special form testing. In one test, an inner capsule with a volume of about $1008 \mathrm{~cm}^{3}$ was 
TABLE 3.7. Volumes of WESF Inner Capsules and the Annular Space Between Inner and Outer Capsules at $25^{\circ} \mathrm{C}$ and $800^{\circ} \mathrm{C}(\mathrm{a})$

\begin{tabular}{|c|c|c|c|c|c|}
\hline \multirow[b]{2}{*}{$\begin{array}{c}\text { Capsule } \\
\text { Type } \\
\end{array}$} & \multirow{2}{*}{$\begin{array}{c}\text { Approximate } \\
\text { Dates Capsules } \\
\text { Were Filled }\end{array}$} & \multirow[b]{2}{*}{ Temperature, ${ }^{\circ} \mathrm{C}$} & \multicolumn{2}{|c|}{ Volume, $\mathrm{cm}^{3}$} & \multirow[b]{2}{*}{$\begin{array}{l}\text { Number of } \\
\text { Capsules }\end{array}$} \\
\hline & & & Inner & $\begin{array}{l}\text { Annular Between } \\
\text { Inner and Outer }\end{array}$ & \\
\hline 1 & $\begin{array}{l}\text { Sept } 1974 \text { to } \\
\text { May } 1977\end{array}$ & $\begin{array}{r}25 \\
800\end{array}$ & $\begin{array}{l}1014 \pm 22 \\
1059 \pm 23\end{array}$ & $\begin{array}{l}178 \pm 15 \\
186 \pm 16\end{array}$ & 216 \\
\hline 2 & $\begin{array}{l}\text { May } 1977 \text { to } \\
\text { Mar } 1979\end{array}$ & $\begin{array}{r}25 \\
800\end{array}$ & $\begin{array}{r}999 \pm 22 \\
1044 \pm 23\end{array}$ & $\begin{array}{l}178 \pm 15 \\
186 \pm 16\end{array}$ & 165 \\
\hline 3 & $\begin{array}{l}\text { Mar } 1979 \text { to } \\
\text { Oct } 1983\end{array}$ & $\begin{array}{r}25 \\
800\end{array}$ & $\begin{array}{l}947 \pm 31 \\
984 \pm 32\end{array}$ & $\begin{array}{l}147 \pm 28 \\
154 \pm 29\end{array}$ & 1174 \\
\hline
\end{tabular}

(a) Changes in the specified wall thickness of the inner capsule account for the changes in capsule

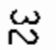
type. 


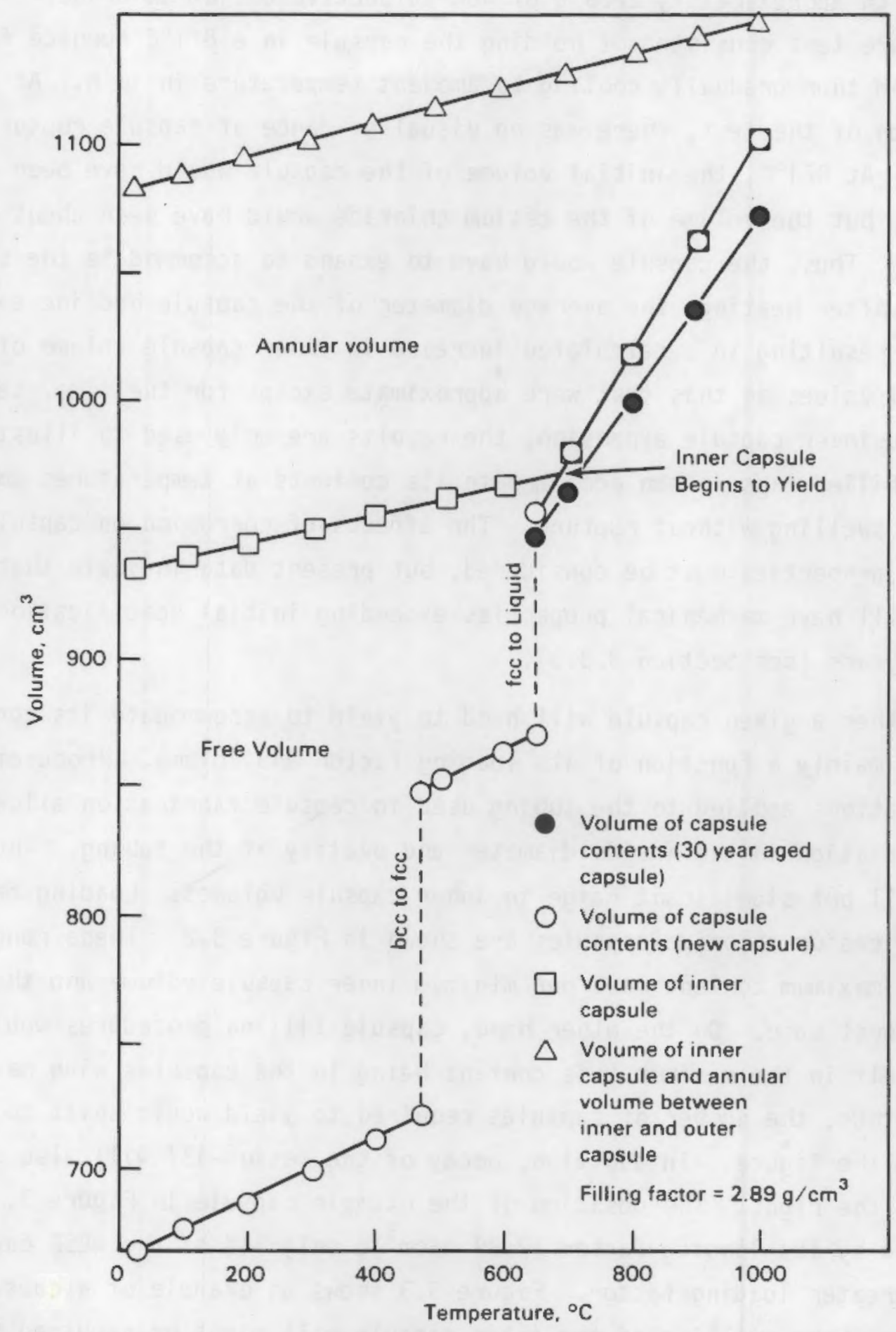

FIGURE 3.1. Volume Changes with Temperature for a New and a 30-Year-01d WESF Capsule (Type 3, Table 3.4) Showing That the Inner Capsule Yields at Temperatures Above About $700^{\circ} \mathrm{C}$ But That the Outer Capsule Does Not Yield Even at Temperatures Greater Than $1000^{\circ} \mathrm{C}$. The volume of WESF cesium chloride at temperatures greater than the cesium chloride melting point decreases with increased age. 
filled with approximately $2770 \mathrm{~g}$ of nonradioactive cesium chloride. The hightemperature test consisted of holding the capsule in a $871^{\circ} \mathrm{C}$ furnace for 90 min and then gradually cooling to ambient temperature in $16 \mathrm{~h}$. At the conclusion of the test, there was no visual evidence of capsule rupture or leaking. At $871^{\circ} \mathrm{C}$, the initial volume of the capsule would have been about $1057 \mathrm{~cm}^{3}$, but the volume of the cesium chloride would have been about $1084 \mathrm{~cm}^{3}$. Thus, the capsule would have to expand to accommodate the salt volume. After heating, the average diameter of the capsule had increased by $0.48 \mathrm{~mm}$, resulting in a calculated increase in inner capsule volume of $20 \mathrm{~cm}^{3}$. Since all values in this test were approximate except for the time, temperature, and inner capsule expansion, the results are only used to illustrate that a newly filled capsule can accommodate its contents at temperatures above $800^{\circ} \mathrm{C}$ by swelling without rupture. The effects of corrosion on capsule mechanical properties must be considered, but present data indicate that capsules still have mechanical properties exceeding initial specifications even after 6 years (see Section 3.3.3).

Whether a given capsule will need to yield to accommodate its contents at $800^{\circ} \mathrm{C}$ is mainly a function of its loading factor and volume. Procurement specifications applied to the tubing used in capsule fabrication allow for a small variation in the inside diameter and ovality of the tubing. Thus, there is a small but significant range in inner capsule volumes. Loading factors for all WESF cesium chloride capsules are shown in Figure 3.2. These ranges are based on maximum content mass per minimum inner capsule volume and thus indicate a worst case. On the other hand, capsule filling procedures would generally result in the maximum mass content being in the capsules with maximum volume; thus, the number of capsules required to yield would shift to the right in the figure. In addition, decay of the cesium-137 will also cause a shift to the right. The position of the example capsule in Figure 3.1 is indicated by its loading factor $\left(2.89 \mathrm{~g} / \mathrm{cm}^{3}\right)$; on $1 y 14 \%$ of the WESF capsules have a greater loading factor. Figure 3.3 shows an example of a capsule in the range where swelling of the outer capsule wall might be required to occur (loading factor $=3.07 \mathrm{~g} / \mathrm{cm}^{3}$ ). In this case, where the predicted swelling is exaggerated by coupling maximum salt mass with minimum inner capsule volume, outer capsule swelling at $800^{\circ} \mathrm{C}$ is not predicted. As indicated by 


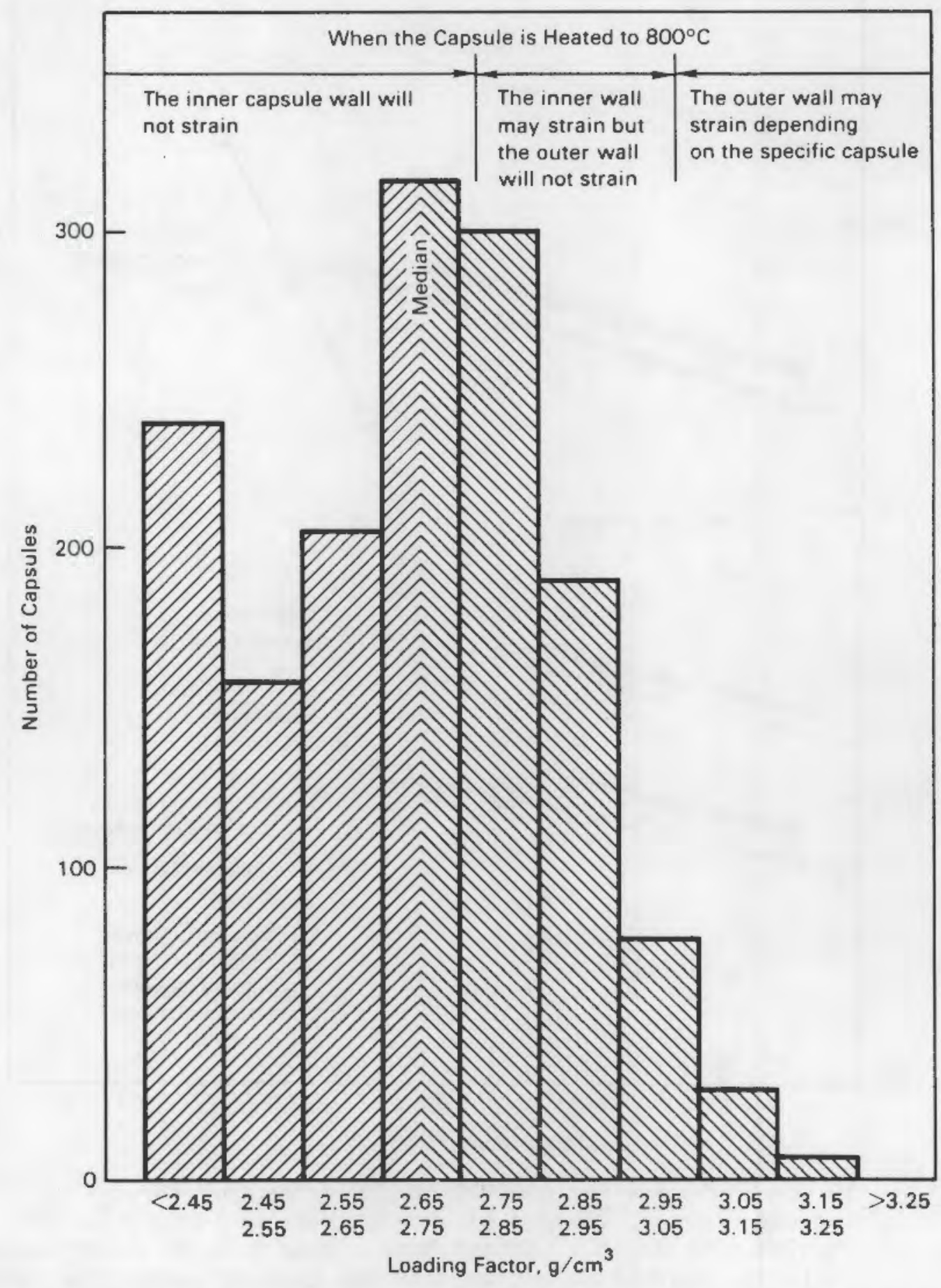

FIGURE 3.2. Distribution of Loading Factors in WESF Cesium Chloride Capsules 


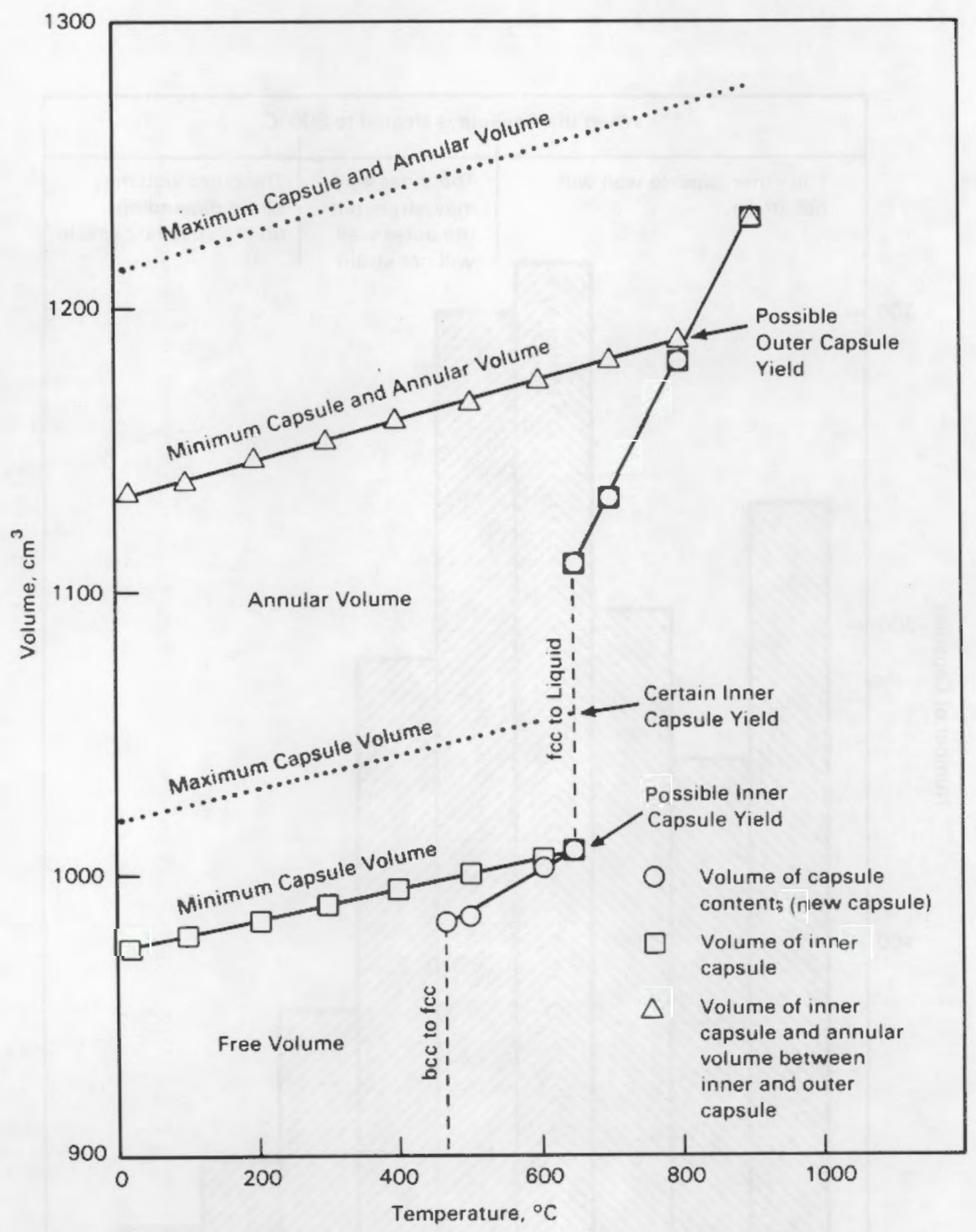

FIGURE 3.3. Volume Changes with Temperature for a New Maximum-Loaded WESF Capsule (Type 2, Table 3.4) Showing Minimum Capsule Volume Coupled with Maximum Content Mass. Note that no outer capsule yield is required to accommodate the capsule contents at $800^{\circ} \mathrm{C}$. 
Figure 3.2, nearly ail WESF capsules have a smaller loading factor than $3.07 \mathrm{~g} / \mathrm{cm}^{3}$. If maximum inner capsule volume were coupled with maximum salt mass, as would be expected, only one WESF capsule would need outer capsule swelling to accomodate its contents at $800^{\circ} \mathrm{C}$. Furthermore, swelling of both inner and outer capsules could occur without rupture or release of radioactive cesium chloride.

\subsubsection{Summary of Thermal Expansion Analys is}

The WESF capsules can be categorized into three groups according to swelling tendency at $800^{\circ} \mathrm{C}$. More than $64 \%$ of the capsules will not swell at all; less than $4 \%$ are likely to have outer capsule swelling; and the rest of the capsules may have inner capsule swelling but will not have outer capsule swelling. Based on expected densities and chemical reactions, the extent of the potential swelling is expected to decrease with increased capsule age because of radioactive decay and reactions of the decay product barium with salt contaminants. There is little question that capsules not damaged by corrosion can safely contain the contents at $800^{\circ} \mathrm{C}$.

At the present time, data are available on 6-year-old capsules that have been in irradiator service for 27 months; tests are currentiy under way on capsules used in the sioss for about 5 years. These tests will supply information on the mechanical properties of the metal container material and the effect of the very low corrosion levels of these properties. In any case, inner capsule swelling could occur to the limits of the outer capsule under accident conditions without any potential of rupturing the capsule. This would include more than $96 \%$ of the capsules presently available. Furthermore, modest outer capsule swelling appears to be acceptable and, if permitted, all WESF capsules could be used. A further safety margin is achieved with little consequence to cesium-137 supply or to the operating costs of an irradiator by the recent $D O E$ decision to use the most heavily loaded capsules for medical garma sources to be reincapsulated at ORNL. The estimated demand for these sources is about $1 \mathrm{MC} ;$ of cesium- 137 or about 20 capsules. Thus, removal of 20 of the most heavily loaded capsules leaves no capsules with potential outer capsule swelling available for irradiator use. 


\subsection{CAPSULE MECHANICAL PROPERTIES}

Although the detailed designs of applications for the WESF cesium chloride capsule have not been completed at this time, it is extremely unlikely that the capsule will be subjected to mechanical stresses during normal service or storage that would threaten its structural integrity. The consequences of such stresses have been assessed, however, as part of the evaluation of the effect of mechanical or thermal forces acting on the capsule.

During a 3-year testing program, 316L SS was chosen from the candidate materials (316L SS, Hastelloy $C$, and Hastelloy $C-276$ ) as the superior material for containment of radioactive cesium chloride for extended periods of time (Fullam 1972). The choice was based on the resistance of $316 \mathrm{~L}$ SS to corrosion attack at temperatures up to $600^{\circ} \mathrm{C}$, its strength at high temperatures, its ductility, and its weldability. The strength and ductility of the capsule-including general capsule properties testing that has indicated its ability to withstand impact, percussion, and swelling--and the mechanical properties of an aged capsule are discussed in this section. Weld quality will be discussed in Section 3.4 .

\subsubsection{General Mechanical Properties of Capsules}

Minimum strength and ductility properties of capsule tubing were specified by Atlantic Richfield Hanford Company (1974-1978). The properties are shown in Table 3.8. The end caps are the same material and have similar properties. Tests performed to assure that capsule tubing passed the specified standards included ductility and soundness, flaring, hydrostatic, surface condition, and ultrasonic examination (Atlantic Richfield 1974-1978).

Dimensional toler ances were set by the standard as shown in Table 3.9. Details of the capsule are shown in Figure 1.1. Eccentricity limits were set at $\leq 10 \%$ of the wall thickness and staightness was set at 0.010 in. per 1 inear foot. The tubing was made by the seamiess process. The ends of the capsules were machined during fabrication for proper fit of the end caps, and the inner capsule was sized on one end to accept a sintered metal disk and an 0 ring retainer. On the inner tube, the ends were machined in 1 in. from one end 
TABLE 3.8. Minimum Strength and Ductility Standards of $316 \mathrm{~L}$ SS Tubing Used in WESF CSCl Capsules (Atlantic Richfield 1974-1978)

\begin{tabular}{|c|c|c|c|}
\hline Temper ature, & $\begin{array}{c}\text { Minimum } \\
\text { Tensile Strength, } \\
\text { psi }\left(\begin{array}{l}a) \\
\end{array}\right.\end{array}$ & $\begin{array}{c}\text { Minimum } \\
\text { Yield Strength } \\
0.2 \% \text { Offset, psi }\end{array}$ & $\begin{array}{l}\text { Minimum } \\
\text { Elongation } \\
\text { in } 2 \text { in., } \% \\
\end{array}$ \\
\hline 25 & 75,000 & 30,000 & 35 \\
\hline 538 & 50,000 & 15,000 & 30 \\
\hline $800^{(b)}$ & 7,500 & 3,000 & 20 \\
\hline
\end{tabular}

(a) Pounds per square inch.

(b) Evaluated from general 316 SS data.

TABLE 3.9. Dimensional Tolerances of WESF Tubing (Atlantic Richfield 1974-1978)

Inner Capsule, in.
Outer diameter
Wall
Length
Cap thickness
Outer Capsule, in.

Capsule Type

Inner diameter

Wall

Length

Cap thickness

$$
\begin{gathered}
2.407 \pm 0.008 \\
0.109 \pm 0.009 \\
20.775 \\
0.400
\end{gathered}
$$$$
2.407 \pm 0.008
$$$$
2.385 \pm 0.015
$$$$
0.119 \pm 0.009
$$$$
0.136 \pm 0.012
$$$$
20.775
$$$$
20.775
$$

0.400

and $1 / 4 \mathrm{in}$. From the other end to $2.086 \pm 0.001$ in. inner diameter and to $2.246 \pm 0.001 \mathrm{in}$. outer diameter, leaving a 0.08-in. wall. The outer capsule was machined in $1 / 4 \mathrm{in}$. on each end to $2.619 \pm 0.00 \mathrm{l} i \mathrm{n}$. outer diameter and $2.419 \pm 0.001$ in. inner diameter, leaving a $0.10-i n$. wall. Quality control on capsule materials and fabrication is impressive and leaves little doubt as to capsule quality. 
From the capsule properties and dimensions, the internal pressure at which the capsule wall will yield can be calculated. At $25^{\circ} \mathrm{C}$, that calculation indicates that both inner and outer capsules will stand more than 5000 psi even considering the thinner walls at the machined ends. This conclusion is consistent with burst test results performed during weld development (see Section 3.4). During that testing, both inner and outer capsule tubing consistently burst at pressures between 5000 and 6000 psig.

When welding penetration was adequate, the mechanism for bursting was observed to be bulging and stretching the tube wall. At higher temperatures, the strength and ductility of $316 \mathrm{LS}$ decreases until, at $800^{\circ} \mathrm{C}$, the strength is $10 \%$ of the strength at $25^{\circ} \mathrm{C}$ and the minimum elongation is $20 \%$ in 2 in. as show in Table 3.8. Thus, at $800^{\circ} \mathrm{C}$, each capsule would be strong enough to withstand more than 500 psi and permit substantial bulging before rupture; however, no specific testing has been done to verify these higher temperature properties on actual WESF capsules.

\subsubsection{Impact, Percussion, and Fire Tests}

J. E. Hammond (1975) conducted physical testing of the WESF cesium chloride capsules in the as-fabricated condition. The testing included impact (drop), percussion, and fire tests.

The drop test used by Hammond was similar to the test defined in the IAEA Safety Series No. 33 (IAEA/ENEA 1970), except that the drop distance was $10 \mathrm{~m}$ instead of $9 \mathrm{~m}$. To meet test requirements, the capsule should impact an unyielding surface at an angle that will produce maximum damage to the capsule, i.e., the capsule should be dropped on its sharpest corner or weakest point. $H$ ammond reported that the capsules appeared to impact at angles varying between $15^{\circ}$ and $45^{\circ}$ from the vertical. Hammond reported that visual and metallographic examinations of the end caps showed no evidence of cracking and that the capsules did not rupture or leak.

In the percussion test used by Hammond, the capsule was placed in a horizontal position on a concrete floor and struck with a l-in. diameter steel rod having an impact energy of either 10 or $18 \mathrm{ft}-3 \mathrm{~b}(1.4$ or $2.6 \mathrm{~kg}-\mathrm{m})$. The capsules were impacted about midway along their length. Measurements indicated 
that a 0.010 -in. impression was made in the wall of the capsules. No visua? evidence of failure was observed after testing.

The fire test used one complete capsule (i.e., a cesium-chloride filled inner capsule inside an outer capsule) and a filled inner capsule only. These same capsules had been subjected to the drop and percussion tests. In the fire test, the capsules were placed in a furnace preheated to $815^{\circ} \mathrm{C}$, then the furnace temperature was increased to $871^{\circ} \mathrm{C}$ and held at that temperture for 90 min. The furnace was turned off and allowed to cool for $16 \mathrm{~h}$ before the capsules were removed and examined. There was no visual evidence of capsule failure. The inner capsule was removed from the outer capsule and both inner capsules were carefully measured for swelling of the capsule wall. The results of measurements are shown in Table 3.10. As indicated, modest wall swelling was observed for the unencapsulated inner capsule, but very little swelling was observed for the encapsulated inner capsule. Although no explanation was given for this difference, it was apparent from the data that the unencapsulated inner capsule had a greater loading factor than the encapsulated one.

The greater swelling observed at the top and bottom of each capsule could be due to either or both of two reasons: 1) the wall is thinner at both the top and bottom for a short distance and 2) the capsule could have bulged on the ends during impact testing. In any case, it is apparent from the fire test that capsules can undergo rodest bulging without rupture, al though subsequent testing was 1 imited to visual inspection and metallographic examination, which reved led no leaks. No hel ium leak checking was attempted.

These tests, along with others performed during the development of the capsules (Kenna 1982), were conducted to evaluate the mechanical properties of the capsule and to a major extent meet the requirements outlined in ANSI N542, class 6. Table 3.11 compares the tests conducted with those outlined in the standard. The test conditions were equivalent or exceeded the Class 6 requirements except for the external pressurization test, which exceeded only class 3 requirements. For irradiators, it would appear that 47-atm pressure would exceed any anticipated accidental pressures. 
TABLE 3.10. Outer Diameter of A) I solated Inner Capsule and B) Inner Capsule That Was Tested Inside the Outer Capsule After the Capsules Had Been Held in a $871^{\circ} \mathrm{C}$ Furnace for $90 \mathrm{~min}$ and Cooled Gradually. Before testing, the outer diameter of the capsules was $2.250 \pm 0.002 \mathrm{in}$.

\begin{tabular}{ccc}
$\begin{array}{c}\text { Inches From } \\
\text { Bottom }\end{array}$ & \multicolumn{2}{c}{ Capsule Diameter, in. } \\
\cline { 1 - 2 } Bottom & 2.295 & 2.257 \\
2 & 2.288 & 2.250 \\
4 & 2.281 & 2.250 \\
6 & 2.276 & 2.252 \\
8 & 2.271 & 2.249 \\
10 & 2.270 & 2.251 \\
12 & 2.268 & 2.250 \\
14 & 2.266 & \\
16 & 2.265 & 2.249 \\
18 & 2.262 & 2.250 \\
Top & 2.290 \\
& & 2.250
\end{tabular}

\subsubsection{Mechanical Properties of Aged Capsules}

The WESF capsules can suffer corrosion during manufacture and service (see Section 3.1). This corrosion will affect the mechanical properties of the capsule and its ability to withstand mechanical stresses without failing. Two examples of corrosion were discussed previously: 1)pitting that occurred to depths of up to $9 \%$ of the capsule wall thickness, observed on the outer surfaces of some inner capsules, which are believed to have resulted from manufacturing operations and 2) internal corrosion of the inner capsule by the cesium chloride and/or impurities. Since these capsules will be subjected to on $1 y B$ and $Y$ radiation, the radiation exposure will have little or no effect on mechanical properties.

In an effort to test the effect of aging on mechanical properties, longitudinal tensile specimens were cut and tested from the 6-year-old WESF cesium chloride capsule that had seen service in the SIDSS facility for 27 months (Kenna and Schultz 1983). The results are shown in Table 3.12. It is apparent from these results that aging reduces strength and increases ductility 
TABLE 3.11. Comparison of Test Conditions Required by ANSI N542 Class 6 (National Bureau of Standards 1978) with Test Conditions Used for WESF Cesium Chloride Capsules

\begin{tabular}{|c|c|c|}
\hline Test & ANSI N542 Requirements & WESF Capsule Test Conditions \\
\hline Temper ature & $\begin{array}{l}+800^{\circ} \mathrm{C}(1 \mathrm{~h}) \\
-40^{\circ} \mathrm{C}(20 \mathrm{~min})\end{array}$ & $\begin{array}{l}871^{\circ} \mathrm{C} \quad(90 \mathrm{~min}) \\
\mathrm{N} / \mathrm{A}\end{array}$ \\
\hline Thermal shock & $800^{\circ} \mathrm{C}$ to $20^{\circ} \mathrm{C}$ & $\begin{array}{l}800^{\circ} \mathrm{C} \text { to } 20^{\circ} \mathrm{C} \\
10 \text { times }(\mathrm{b})\end{array}$ \\
\hline $\begin{array}{l}\text { Pressure } \\
\quad \text { External (a) }\end{array}$ & $\begin{array}{l}25 \mathrm{kN} / \mathrm{m}^{2} \text { abs to } \\
170 \mathrm{MN} / \mathrm{m}^{2} \text { abs } \\
(0.24 \text { to } 1677 \text { atm })\end{array}$ & $\begin{array}{l}103 \mathrm{kN} / \mathrm{m}^{2} \text { to } \\
4.8 \mathrm{MN} / \mathrm{m}^{2} \text { abs }(\mathrm{b}, \mathrm{c}) \\
(1.0 \text { to } 47.3 \text { a tm })\end{array}$ \\
\hline Internal (a) & -- & $\begin{array}{l}46.7 \mathrm{kN} / \mathrm{m}^{2} \text { to } \\
52.8 \mathrm{MN} / \mathrm{m}^{2} \\
(0.466 \text { to } 544 \mathrm{~atm})\end{array}$ \\
\hline Impact & $\begin{array}{l}20 \mathrm{~kg}(44 \mathrm{lb}) \\
\text { weight dropped } \\
\text { from } 1 \mathrm{~m} \\
(89 \mathrm{~kg}-\mathrm{m} / \mathrm{s})(\mathrm{d})\end{array}$ & $\begin{array}{l}5 \mathrm{~kg}(11 \mathrm{lb}) \text { weight } \\
\text { dropped from } 1 \mathrm{~m} \\
\text { (22 } \mathrm{kg}-\mathrm{m} / \mathrm{s}) ; \text { also free } \\
\text { drop of } \mathrm{filled}(7.3 \mathrm{~kg} \\
\text { or } 16.3 \mathrm{lb}) \text { capsuje from } \\
10 \mathrm{~m}(102 \mathrm{~kg}-\mathrm{m} / \mathrm{s})(\mathrm{d})\end{array}$ \\
\hline Vibration & Not used & No test performed \\
\hline Puncture & $\begin{array}{l}1 \mathrm{~kg}(2.2 \mathrm{lb}) \text { pointed } \\
\text { rod dropped on to } \\
\text { capsule from height } \\
\text { of } 1 \mathrm{~m}\end{array}$ & $\begin{array}{l}\text { Complete capsule }(>7 \mathrm{~kg}) \\
\text { dropped from neight of } \\
4.6(\mathrm{~m} \text { onto pointed } \\
\operatorname{rod}(\mathrm{b})\end{array}$ \\
\hline
\end{tabular}

(a) The internal pressure test is used in place of the reduced external pressure test and exceeds the requirement in terms of force per unit area experienced by the capsule.

(b) Tests performed by J. Dunn (Kenna 1982, p. 24).

(c) Test exceeds the requirements of ANSI N542 Class 3 but does not meet the requirements of ANSI N542 Class 6 . Tests meet or exceed ANSI N542 Class 6 requirements in all other cases.

(d) The momentum at impact of $89 \mathrm{~kg}-\mathrm{m} / \mathrm{s}$ for the ANSI N542 requirement is fully met by the WESF capsule test momentum, which was $302 \mathrm{~kg}-\mathrm{m} / \mathrm{s}$. 
TABLE 3.12. Summary of Mechanical Properties at $25^{\circ} \mathrm{C}$ of "New" and "Aged" (6 years old) 316L SS from CsCl Capsules

\begin{tabular}{c}
$\begin{array}{c}\text { Tensile Strength, Yield Strength, } \\
1000 \text { psi(a) }\end{array}-\begin{array}{c}\text { Elongation in } \\
2 \text { in., \% }\end{array} \quad \begin{array}{c}\text { Reduction } \\
\text { Area, } \%\end{array}$ \\
\hline
\end{tabular}

Outer Capsule

\begin{tabular}{llllr} 
New & $96.2 \pm 2.5$ & $47.6 \pm 3.4$ & $53.8 \pm 2.8$ & $64.3 \pm 3.6$ \\
Aged & $82.1 \pm 3.3$ & $38.1 \pm 1.6$ & $65.6 \pm 2.9$ & $71.8 \pm 1.8$ \\
Inner Capsule & & & & \\
\hline Aged & $82.1 \pm 3.9$ & $41.0 \pm 3.3$ & $59.3 \pm 4.7$ & $72.2 \pm 2.7$
\end{tabular}

(a) 1000 pounds per square inch. 
in the capsule material. However, these changes are relatively small, and it should be noted that the aged capsule material still exceeded the specifications for new capsule material (compare Tables 3.12 and 3.8). These metal property changes are expected from annealing by the higher irradiator temperatures and the irradiation. These changes should saturate rather quickly, and little or no further change is expected. There was no indication that corrosion had caused the decrease in yield and ultimate strength of the inner capsule since both the inner and outer capsules suffered similar losses in strength.

\subsection{CAPSULE WELD QUALITY}

Weld quality is an important consideration in assuring the safety of WESF ces ium chloride capsules. An extensive weld development and testing program was completed before encapsulation was begun (0'Brien 1974). A remote, automatic welder was fabricated and tested on numerous dumny capsules before being used in the hot cell. Extensive destructive evaluations, including metallography and burst tests, were performed on the dumny capsules to assure weld quality and to set minimum penetration standards. These standards assured that the weld was stronger than the tube wall and were initially set at $75 \%$ of the wall thickness at the weld. Later, through improved welding procedures, the minimum penetration was decreased to $55 \%$ of the wall thickness. Capsules were subjected to internal pressures of more than 5000 psig until the wall would yield but the weld would not yield. At penetrations of less than $45 \%$, the weld sometimes failed before the wall. The welding procedure was set up such that the threshold current would assure penetrations of at least $45 \%$.

Three nondestructive weld evaluation methods were developed to assure weld integrity and were performed on every capsule. The inner capsule welos were subjected to two leak detection tests, and the outer capsule weids and one inner capsule weld were examined by ultrasonics.

Two leak detection methods were developed to assure a leak-free inner capsule (Niemeyer 1972; Haff, Nieneyer, and Robinson 1967). After welding and thorough visual inspection of the weld, a helium leak check and a bubble test in water were performed on each inner capsule. 
The leak check procedures were as follows. Helium was incorporated into the cesium chloride voids and into the pores of a sintered metal disk by a 15-min purge just before the final inner capsule weld. With in 7 days after welding, the inner capsule was placed in a vacuum chamber, evacuated, and the residual gas was analyzed by mass spectrometry. Helium would be detected by the mass spectrometer from a capsule with a leak larger than $3 \times 10^{-8} \mathrm{~cm}^{3} / \mathrm{s}$. A very large leak may not be detected by this method because the gas from inside the capsule could be depleted during the initial evacuation; therefore, a bubble test was performed on each capsule by immersing the capsule in water for at least $30 \mathrm{~min}$ and watching for any unusual activity or bubbling around the welds. It should be noted that all leaks, even large ones purposely produced during weld development studies, resulted in a positive helium leak test.

After leak detection, the capsules were decontaminated by successive ultrasonic baths. During 1980, a new method of decontamination was initiated. The new method involved electropolishing the inner capsule in an electrochemical cell for about 20 min (40 min maximum) at 170 amp or until decontaminated. This process removed 15 to $20 \mathrm{~g}$ or about $0.001 \mathrm{in}$. of metal from the surface of the capsule. After the decontamination step, the welds were again visually inspected but not helium leak checked or bubble tested before the inner capsule was placed inside the outer capsule. The probability of a leak resulting from the decontamination procedures is considered to be very small because of the small amount of metal removed and because of the $45 \%$ minimum weld penetration assurance.

The ultrasonic inspection system was designed to determine weld penetration and locate any significant flaws (Crowe 1971). After a thorough visual inspection, ultrasonic inspection was performed on both outer capsule welds to assure a defect-free weld of sufficient penetration and strength. Scans of the welds were placed in a permanent file.

Welding and testing procedures are impressive and have resulted in a perfect record on the approximately 2000 capsules produced (including the strontium- 90 capsules). No leaks have ever been observed after the capsules have passed the weld integrity tests. 


\subsection{CONCLUSIONS}

The WESF cesium chloride waste capsules are well engineered for their intended use: safe storage of the major radiation-producing fission product isotopes. These capsules also meet the requirements for beneficial use as an irradiation source because they are in many ways similar. Evidence of the integrity of the capsules comes from the experience with large numbers of capsules at Hanford as well as from laboratory and qualification testing of the sources. To date, over 1500 of the double-walled capsules containing cesium chloride have been fabricated and stored in the WESF pool for up to 10 years without a single leak. Fifteen of the capsules were removed from the pool in 1979 for use in the SIDSS facility and have been in that environment since then. Three of the capsules have since been removed from SiDSS for examination; the first was removed in 1982 and the other two in May 1984. The results from the 1982 examination showed no evidence of significant corrosion or salt degradation, and the metals properties still exceeded the initial metal specifications. The other two capsules, recently removed from the irradiator, are currently being examined. In addition, a large number of smaller capsules containing radioactive cesium chloride have been fabricated at ORNL for use in medical facilities. Some have now been in service for over 20 years with no reported radioactivity releases or other safety problems.

Corrosion data have been generated for various conditions at several laboratories. These data indicate that corrosion rates are very low at anticipated irradiator temperatures and corrosion appears to be of little consequence. This conclusion is supported by data from the one SIDSS capsule held at 200 to $250^{\circ} \mathrm{C}$ for 27 months following storage in the WESF pool for 4 years. Additional information on temperature effects, corrosion by impurities, and corrosion mechanisms was obtained from a study of corrosion rates at projected geologic storage temperatures. Relatively large corrosion rates were observed in this study where the capsules were held at a $450^{\circ} \mathrm{C}$ salt/stainless steel interface temperature. The corrosion was attributed largely to impurities in the salt. The corrosion rate of the capsule held at $300^{\circ} \mathrm{C}$ is expected to be much larger than the low-temperature rates; but since the time at temperature 
is expected to be less at $90 \mathrm{~min}$, the total corrosion will be small, i.e., approximately the same as that which occurred when the salt was poured into the capsule at 730 to $750^{\circ} \mathrm{C}$.

Some corrosion was also observed on the outer surface of the inner capsule of a few sources. This corrosion, caused by electropolishing used to decontaminate the capsules, produced pits in the surface up to a depth of about $9 \%$ of the wall thickness. Since this attack is not expected to continue, the only anticipated effect on the capsule quality is a small reduction in capsule strength.

The strength of the metal container for the cesium chloride is assured by specifying capsule properties and by carefully monitoring the material as received. The capsules were designed to meet the criteria established for sealed sources, and tests have been conducted to demonstrate compliance. Thus, drop tests, percussion tests, and thermal treatments have been completed without any capsule failure. The strength and ductility of a 6-year-old capsule that had been used in SIDSS for 27 months were measured and compared with those of a new capsule. The comparison reflected a $10 \%$ to $15 \%$ loss of strength and a similar increase in ductility, but the residual mechanical properties still met the initial specifications of the material.

If capsules are accidentally heated to $300^{\circ} \mathrm{C}$, inner capsule swelling from thermal expansion of the salt and pressurization of the gas would occur in no more than one in three of the capsules. Even in these cases, there is no significant potential for rupture because the strength and ductility of the metal permits up to $44 \%$ capsule expansion without rupture, about three times that expected from the capsule containing the most salt. The decay of cesium-137 is expected to decrease the salt volume at high temperature, rather than increase it, because reaction of the metallic barium with salt impurities leads to a more dense species than the original CSCl. Minor outer capsule swelling is projected for a very few capsules (perhaps only one) at $800^{\circ} \mathrm{C}$, and these capsules could be used for other purposes. However, it is concluded that swelling to the extent where the outer capsule also expands to a small extent will not cause a rupture.

Licensing criteria have not been established for WESF capsules, which contain large quantities of radioactive material. It appears, however, that 
previous testing largely covers those areas of concern for the safe performance of the capsules in irradiators. Work is continuing, however, to obtain longer term data on corrosion, to verify the integrity of the capsules at $800^{\circ} \mathrm{C}$, to assess potential loss of strength in the stainless steel, and to obtain data on the effects of thermal cycling. Planned future work will assure the safety of the capsules by obtaining data well in advance (about 10 years) of a comparable exposure in the first commercial irradiators. 
$\downarrow$ 


\subsection{REFERENCES}

Al Jegheny Ludlum Steel Corporation. 1959. Stainless Steel Handbook. Pittsburgh, Pennsylvania.

Atlantic Richfield Hanford Co. 1974-1978. Specification for Seamless 316-L Austenitic Stainless Steel Tubing. HWS-8835, Rev. T-9, Richland, Washington.

Bryan, G. H. 1983. Cesium Chloride Compatibility Testing Program Annual Report - Fiscal Year 1983. PNL-4847, Pacific Northwest Laboratory, Richland, washington.

Crowe, J. C. 1971. "Techniques for Nondestructive Evaluation of Radioactive Was te Capsule End Cap Welds." BNWL-SA-3758, Pacific Nor thwest Laboratories, Richland, Wash ington.

U.S. Department of Energy. 1983. Department of Energy Plan for Recovery and Utilization of Nuclear Byproducts from Defense Wastes. DOE/DP-0013, 2:2.1.

Fullam, H. T. 1972. Compatibility of Cesium Chloride and Strontium Fluoride with Containment Materials. BNWL- 673 , Pacific Northwest Laboratory, Richtand, Wash ington.

Fullam, H. T. 1982. Cesium Chloride Compatibility Testing Program Annual Report - Fiscal Year 3982. PNL-4556, Pacific Northwest Laboratory, Richland, Washington.

Haff, K. W., R. G. Niemeyer, and R. A. Robinson, 1967. "Radioisotope Source Safety Testing." Oak Ridge National Laboratory, Oak Ridge, Tennessee.

Hammond, J. E. 1975. Cesium Chloride Capsule Testing for Special Form Qualification. ARH-CD-440, At Tantic Richfield Hanford Co., Richland, Washington.

Honeyman, J. 0. 1980. Cesium Chloride Phase Expansion Effects on Capsule Storage Assembly Integrity-A Summary. RHO-CD-964, Rockwell Hanford operations, Richland, Washington.

IAEA/ENEA. 1970. "Guide to the State Design Construction and Use of Radioisotopic Power Generators for Certain Land and Sea Applications." IAEA Safety Series No. 33, ISBN 92-0-123070-2, Unipub, New York.

Jackson, R. R. 1977. "Hanford Waste Encapsulation: Strontium and Cesium." Nuc ]. Tech. 32:10-15.

Kenna, B. T. 1982. WESF 137C S Gamma Ray Sources. SAND 82-1492, Sandia National Laboratories, Albuquerque, New Mexico.

Kenna, B. T., and F. J. Schultz. 1983. Characterization of an Aged WESF Capsule. SAND 83-0928, Sandia National Laboratories, Albuquerque, New Mexico, and Livermore, Cal ifornia. 
National Bureau of Standards. 1978. American National Standard N 542; Sealed Radioactive Sources, Classification. ANSI N542-1977, American National Standards Instítute, New York.

Niemeyer, R. G. 1972. Leak Testing Encapsulated Radioactive Sources. Oak Ridge National Laboratory, Oak Ridge, Tennessee.

O'Brien, W. H. 1974. Welding Development for the Waste Encapsulation Program, Final Report. Atlantic Richfield Hanford Co., Richland, Washington.

Peker, L. K. 1983. Nuclear Data Sheets. 38 No. 1:147, American National St andards Institute Subcomittee $\sqrt{43-3} .3$.

Rimshaw, S. J., and E. E. Ketchen. 1967. Cesium-137 Data Sheets. ORNL-4186, Oak Ridge National Laboratory, Oak Ridge, Tennessee.

Rohrmann, C. A. 1971. "The Availability and Appljcations of Radioactive and Stable By-Products from the Chemical Processing of Spent Nuclear Power Fuels." In Proceedings of the 10 th Conference on Radioisotopes, Japan Atomic Industrial forum, Inc., pp. 57-68.

Walker, F. W., G. J. Kironac, and F. M. Rourke. 1977. Chart of the Nuclides. 12 th ed. Knolls Atomic Power Laboratory, Schenectady, New York. 
PNL -5170

UC -70

\section{DISTR IBUT ION}

No. of

Copies

OFFSI TE

J. Jicha, Jr.

R\&D and Byproducts

U.S. Department of Energy

Wash ington, DC 20545

W. McMusilen

U.S. Department of Energy

P.0. Box 5400

Albuquerque, NM 87115

A. L. Taboas

U.S. Department of Energy

Wash ington, OC 20545

27 DOE Technical Information Center

K. W. Haff

Dak Ridge National Laboratory

Oak Ridge, TN 37830

E. Lamb

Oak Ridge National Laboratory

Oak Ridge, TN 37830

F. J. Schultz

Oak Ridge National Laboratory

Oak Ridge, TN 37830

B. T. Kenna

Sandia National Laboratories

A lbuquerque, NM 87185

J. D. Pierce

Sandia National Laboratories

A lbuquerque, NM 87185

D. J. Sasmor

Sandia National Laboratories

A lbuquerque, NM 87185

J. L. Tills

Jack L. Tills \& Associates

A lbuquerque, NM 87185
No. of

Copies

\section{ONSITE}

4 DOE Rich land Operations Office

N. T. Karagianes

H. E. Ransom

M. W. Shupe

F. R. Standerfer

6 Rockwell Hanford Operations

K. A. Gasper

M. W. Gibson

D. L. Lamberd

I. E. Reep

R. H. Riech

R. L. Salley

47 Pacific Northwest Laboratory

G. H. Bryan

H. T. Fullam

S. K. Edler

C. R. Hann

P. E. Hart

J. H. Jarrett

G. A. Jensen

H. E. Kjarmo

J. M. Latkovich

R. C. Liikala

J. M. Lytle

J. L. McElroy

A. M. Platt

G. L. Tingey (25)

E. J. Wheelwright

H. H. Van Tisyl

Publishing Coordination (2)

Technical Information (5) 


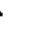

